\title{
Discussion Paper No. 16-065 \\ Responses of Firms to Tax, Administrative and Accounting Rules: Evidence from Armenia
}

Zareh Asatryan and Andreas Peichl

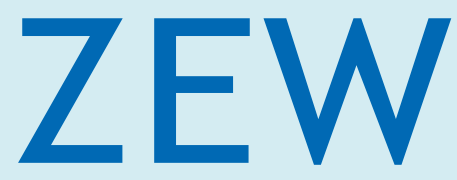

Zentrum für Europäische Wirtschaftsforschung $\mathrm{GmbH}$

Centre for European

Economic Research 


\title{
Discussion Paper No. 16-065 \\ Responses of Firms to Tax, Administrative and Accounting Rules: Evidence from Armenia
}

\author{
Zareh Asatryan and Andreas Peichl
}

Download this ZEW Discussion Paper from our ftp server:

http://ftp.zew.de/pub/zew-docs/dp/dp16065.pdf

Die Discussion Papers dienen einer möglichst schnellen Verbreitung von neueren Forschungsarbeiten des ZEW. Die Beiträge liegen in alleiniger Verantwortung der Autoren und stellen nicht notwendigerweise die Meinung des ZEW dar.

Discussion Papers are intended to make results of ZEW research promptly available to other economists in order to encourage discussion and suggestions for revisions. The authors are solely responsible for the contents which do not necessarily represent the opinion of the ZEW. 


\title{
Responses of Firms to Tax, Administrative and
}

\section{Accounting Rules: Evidence from Armenia}

\author{
ZAREH ASATRYAN ${ }^{* \ddagger} \quad$ ANDREAS PEICHL ${ }^{\dagger \ddagger \delta}$ \\ ‡ZEW Mannheim $\quad$ SUniversity of Mannheim
}

October 5, 2016

\begin{abstract}
Using panel data on the full population of corporate tax returns of Armenian firms, we study the behavioral response of firms to three size-dependent regulations. We find: i) a strong response to an accounting notch where International Financial Reporting Standards become mandatory; ii) a moderate response to an administrative notch below which the frequency of filing and paying taxes declines from monthly to quarterly; and iii) no response to a tax notch created by the registration threshold of the value added tax. Exploiting tax audits, we provide evidence suggesting that income under-reporting drives the bunching response of firms by between 60 and 100 percent. Additional evidence suggests that firms respond to tax audits by compensating every additional dollar of audit driven increase in reported income by a 0.7-0.8 dollar increase in reported deductions.
\end{abstract}

Keywords: Small and medium enterprises, size-dependent regulation, value added tax, tax administration, tax accounting, tax evasion.

JEL codes: H25, H26, O12

*asatryan@zew.de

${ }^{\dagger}$ peichl@zew.de

${ }_{\ddagger}^{\ddagger}$ We would like to thank Michael Alexeev, Miguel Almunia, Pierre Bachas, Benjamin Bittschi, Albrecht Bohne, Anne Brockmeyer, Philipp Dörrenberg, Ulrich Glogowsky, Friedrich Heinemann, Johannes Hermle, David Joulfaian, Jan Kabátek, Armine Khachatryan, Jan Loeprick, Jörg Paetzold, Thomas Schwab, Sebastian Siegloch, Joel Slemrod, Juan Carlos Suárez Serrato, as well as seminar participants at the Oxford University Centre for Business Taxation, the Kiev School of Economics, the Annual MaTax Conference, the ZEW Public Finance Conference, the Armenian Economic Association Meetings, and the International Institute of Public Finance Annual Congress for valuable comments on earlier drafts. We are also grateful to Tigran Baghdasaryan, Ashot Mkrtchyan, Nerses Yeritsyan, and the Central Bank of Armenia for providing access to the administrative data and hosting us during part of this research project. 


\section{Introduction}

In many developing countries inadequate tax capacities and low tax revenues represent one of the main obstacles to economic development (Besley and Persson 2013, 2014). Following the seminal work of Diamond and Mirrlees (1971) the traditional theoretical literature on taxation mainly focuses on the optimal design of tax schedules without paying much attention to various issues related to the tax system as a whole, including tax administration and tax compliance, among others (Slemrod and Gillitzer 2013). While more recent applied research has made important advancements also in the fields of tax administration and tax compliance, particularly owing to the availability of administrative micro datasets and field experiments, the evidence from developing countries remains fairly limited (for surveys see, e.g., Slemrod and Yitzhaki. 2002, Fuest and Zodrow 2013). However, inefficient tax administration and high rates of tax evasion may arguably play a more important role in developing countries, since by limiting the capacity of the state these may have further adverse effects on economic development. On the other hand, in order to design a fair and efficient tax system, policymakers need to have credible empirical evidence on the behavioral impacts of the tax system as a whole (Saez, Slemrod, and Giertz 2012).

Our paper aims at contributing to this debate by studying whether and how firms and particularly smaller firms - in a developing country respond to different incentives created by tax, administrative and accounting rules and policies. We study the behavioral responses of firms to these three sets of policies one-by-one and in a comparative setting, and then show the mechanisms behind the response. The three policies that we study are: i) a tax notch created by the value added tax (VAT) registration threshold; ii) an administrative notch below which the frequency of filing and paying both VAT and corporate income taxes is quarterly instead of monthly for smaller firms; and iii) an accounting notch where International Financial Reporting Standards (IFRS) become mandatory and replace simplified tax accounting rules for small and medium enterprises 
(SME). These regulations that depend on the level of firms' income often play an important role in policy debates because they are one of the central policy instruments in favoring SMEs. However, such size-dependent thresholds where the policy discontinuity is particularly large may also generate incentives for firms, for example, to stay small, thus creating incentives inhibiting firm growth and productivity.

We use the bunching method ${ }^{1}$ and exploit administrative panel data on the universe of corporate tax returns of Armenian firms over the 2007-13 period. A unique feature of the Armenian data is the availability of information on tax audits. Exploiting this data allows shedding light on the mechanisms behind bunching behavior by studying how much of the observed response is due to tax non-compliance. Besides this, Armenia is an interesting developing country to study firms' responses to taxation and tax administration because of its current situation characterized by potentially high rates of tax non-compliance possibly created by weak tax administration. ${ }^{2}$

We make three contributions to the recent and growing literature on firm response to taxes in developing countries. ${ }^{3}$ First, we extend the literature on firm response to VAT registration thresholds to developing countries. ${ }^{4}$ Recent studies by Onji (2009) for Japan, Harju, Matikka, and Rauhanen (2015) for Finland and Liu and Lockwood (2015) for the

\footnotetext{
${ }^{1}$ Saez (2010) and Kleven and Waseem (2013) introduce bunching at kinks and notches respectively. See, e.g., Chetty, Friedman, Olsen, and Pistaferri (2011), Le Maire and Schjerning (2013), Bastani and Selin (2014) for applications of this method in the context of personal income taxation and Devereux, Liu, , and Loretz (2014), Best, Brockmeyer, Kleven, Spinnewijn, and Waseem (2015) for corporate taxation. Kleven (2016) provides a review of the method and the literature. Additionally, Slemrod (2013) discusses the different types of tax notches and estimation of structural parameters using such notches.

${ }^{2}$ The tax administration in Armenia is ranked quite low by international comparisons (such as by the Doing Business report, see more in Section 2), while the shadow economy is said to comprise as much as half of the official economy (see, e.g., International Finance Corporation 2011). Such inefficiencies may seriously impede growth rates, for example, by generating significant costs for business development and economic competitiveness. They are also likely to undermine revenue-raising powers of the central government, thus adversely affecting public finances.

${ }^{3}$ Among others, see Kleven and Waseem (2013), Best et al. (2015) on Pakistan, Carrillo, Emran, and Anita (2012), Carrillo, Pomeranz, and Singhal (2016) on Ecuador, Bachas and Soto (2015) on Costa Rica, Pomeranz (2015) on Chile, Boonzaaier, Harju, Matikka, and Pirttilä (2016) on South Africa, Gebresilasse and Sow (2016) on Ethiopia.

${ }^{4}$ We observe that by now the setting of a registration threshold is a rather universal feature of many VAT systems (see, Table A1 of the appendix for VAT thresholds around the world in 2013). Firms with turnovers above this threshold are required to register and collect the tax, and receive the right of claiming back the tax on their inputs. On the other hand, small firms falling below the threshold that do not register may save considerably on costs related to collecting and remitting the VAT, while the tax authority may save on the administrative costs of VAT since the threshold reduces the number of filers.
} 
UK show that firms respond strongly to such notches by bunching below these thresholds. However, results might be different for developing countries which typically rely heavily on the VAT (Keen and Lockwood 2006, 2010). Armenia is not an exception as almost half of its total tax revenue stems from the VAT (see Figure 1 in Section 2). Moreover, developing countries are typically told to set a higher threshold than more advanced countries due to higher compliance costs. ${ }^{5}$ Analyzing the case of Armenia - which has an unusually large VAT threshold that is higher than in any OECD country - allows us to study whether this intuitive policy advice prevails in practice. We do not find evidence for significant bunching in the distribution of firms around the VAT notch. A plausible interpretation is that the VAT registration threshold in Armenia is set sufficiently high so that the compliance costs of firms of this size, on average, do not outweigh their benefits from registering as VAT payers.

Second, and related to the administrative and accounting policies, our evidence points to the strongest response of firms to the administrative notch where locally set simplified accounting rules can be used instead of having to comply with the IFRS. We find some, but much weaker, response to the administrative notch where the frequency to file and pay taxes decreases from monthly to quarterly for smaller firms. These two results have important policy implications and contribute to the literature on the behavioral responses of firms to tax rates by extending the evidence to administrative policies. While the literature seems to have ignored the question of whether the frequency of filing and paying taxes matters, a body of mostly accounting research studies the impact of IFRS (or USGAAP) adoption on capital markets (see, e.g., Daske 2006, Armstrong, Barth, Jagolinzer, and Riedl 2010, Daske, Hail, Leuz, and Verdi 2013) such as firms' cost of equity capital and liquidity (for an earlier review see, e.g., Ball 2006). Our contribution to this literature

\footnotetext{
${ }^{5}$ The existing literature on optimal indirect taxation models the VAT threshold as a trade-off between tax revenues and potential inefficiencies implied by the differential treatment of firms on one hand, and collection and administration costs on the other hand (Keen and Mintz 2004, Dharmapala, Slemrod, and Wilson 2011, Brashares, Knittel, Silverstein, and Yuskavage 2014, Kanbur and Keen 2014). Higher registration thresholds, however, do not come without costs, as they imply lost tax revenues (especially so for the VAT dependent countries) and more opportunities for informal activity related to a narrowed base for the VAT. Note that Best et al. (2015) show that developing countries can have different optimal tax schemes compared to developed countries.
} 
is to show that firms - SMEs in our case - respond strongly to the mandatory adoption of IFRS by bunching below the income-threshold where the regulation bites. This result is in line with DeGeorge, Ferguson, and Spear (2012), which quantifies a significant and direct cost of IFRS adoption on observable audit costs, increasing these by around $23 \%$ on average in the year of adoption.

Third, we contribute to the literature that tries to quantify tax evasion on the micro level. ${ }^{6}$ We exploit data on tax audits to shed light on the mechanisms behind firm responses. By comparing the estimated excess mass of firms for reported income versus total income (which additionally includes the income detected during audits) and assuming that audits lead to full compliance, we arrive at a lower bound estimate of around 60 percent of the response being driven by income underreporting. Relaxing the assumption that audits lead to full compliance would increase the above estimate. In addition, audited tax returns suggest that firms located just before the notch have about twice higher evasion rates than the ones further away. If we apply more restrictive distributional assumptions on this data, the estimated rate of income underreporting would approach to 100 percent, i.e., the response being entirely driven by income underreporting.

Of course, this evidence cannot be easily interpreted causally when audits are nonrandom. Unfortunately, the audit data does not stem from a random sample of tax returns as in, e.g., Kleven et al. (2011) from Denmark or the Tax Compliance Measurement Program from the US. However, while tax authorities might selectively choose to carry out more and/or stricter audits at firms which they perceive to be suspects of evasion, we do not find the probability of being audited or the strictness of audits (proxied by number of days spent on audits) to be correlated with observed firm characteristics. The smooth distribution of audits around the notch that we find also has a clear policy implication, which is that the tax authorities could improve their audit strategies by targeting firms which have higher incentives to under-report income due to these size

\footnotetext{
${ }^{6}$ For recent papers see, e.g., Marion and Muehlegger (2008), Kleven, Knudsen, Kreiner, Pedersen, and Saez (2011), DeBacker, Heim, Tran, and Yuskavage (2015), Almunia and Lopez-Rodriguez (2014), Best et al. (2015), Casaburi and Troiano (2015), Artavanis, Morse, and Tsoutsoura (2016), Waseem (2016), and for general reviews see Slemrod (2007), Alm (2012)).
} 
dependent regulations. Finally, we find that during years of audits reported income increases, on average, by around 20 percent. However, not all of this translates into higher tax revenues since every additional dollar of audit driven increase in reported income is compensated by a 0.7-0.8 dollar increase in reported costs. This result is line with Carrillo et al. (2016), who show that firms in Ecuador respond to randomized threatof-audit letters by increasing both reported income and reported costs at around the same rate.

The remainder of the paper is structured as follows: Section 2 describes the Armenian tax system in general and the size dependent regulations in particular. Section 3 presents the sample and the data. Section 4 presents the results on the behavioral responses of firms and explores the mechanisms behind the responses. Section 5 concludes.

\section{Institutional Context}

Taxes in Armenia: In Armenia, as in many other developing countries, VAT and corporate income taxes are a major source of tax revenue. This pattern can be seen in Figure 1 with the VAT generating over half of total tax revenue in most years (or around $9 \%$ of GDP), and corporate income taxes coming second with around 15 percent of tax revenue (or around $2 \%$ of GDP). Figure 1 also shows a generally low but increasing tax to-GDP ratio of about 14-17 percent in 2006-2012. Although 2013 saw a large increase in the tax to-GDP ratio, this was mainly due to some of the social security contributions newly classified as part of the personal income taxes. ${ }^{7}$

The VAT in Armenia has a two rate structure with a standard 20 percent rate on imports and the supplies of most goods and services by established firms, and a 0-rate on exports and several exempted goods and services (such as agriculture and financial services). The corporate income tax has a 20 percent flat rate on worldwide income for residents and on income that has a source in Armenia for non-resident entities.

\footnotetext{
${ }^{7}$ Personal income taxes in Armenia are withholding taxes on wages and, therefore, do not apply to firms' income.
} 
Figure 1: Tax Revenue to GDP in Armenia

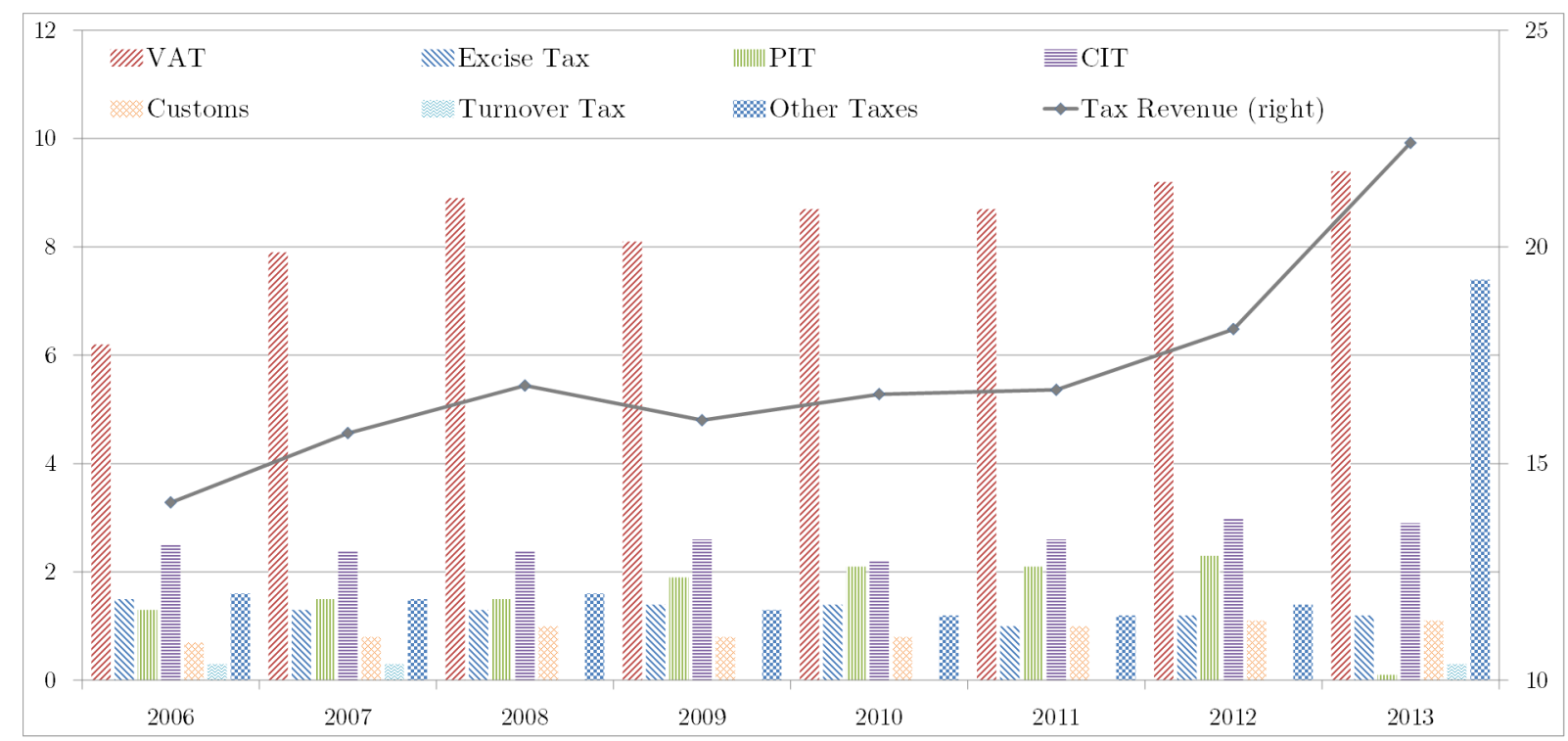

Source: Own compilation based on data from ArmStat.

Notes: The jump in tax revenue to GDP in 2013 is mainly due to a major reform of the PIT system after which some of the social security contributions have been classified as taxes. The PIT revenue to GDP in $2012 / 2013$ amounted to $2,3 / 6,0 \%$, and the social security contributions to GDP added up to $3,2 / 0,4 \%$.

Tax administration: As briefly discussed above, the quality of tax administration in Armenia is a serious concern for its development. According to the World Bank, in 2010 Armenia was ranked 84th in the world by the Ease of Doing Business index with one of the weakest areas being its taxation system at the $163 \mathrm{rd}$ place. ${ }^{8}$ Although recent years have seen some progress with the overall ranking climbing to 50th in 2014, the "paying taxes" rank still lags behind at 74th in the world. This situation may have more to do with various inefficiencies inherent to the country's tax administration rather than to its tax rates. One survey conducted in 2013 among firms and entrepreneurs found that about 50 percent of responses expressed that issues of tax administration are of higher priority than other matters related to tax policy, while the responses naming tax rates as the greatest concern made up about 30 percent (USAID 2014, p. 61). About

\footnotetext{
${ }^{8}$ The Ease of Doing Business index ranks countries according to several categories, such as the ease of starting a business, enforcing contracts, resolving insolvency, registering property, getting credit, etc. One of these categories is the ease of paying taxes, which measures the regulatory burden associated with taxation and includes information on the statuary rates on several taxes for a medium-size limited liability company, as well as the number of payments and the time required to prepare, file and pay these taxes.
} 
Figure 2: TAX REFORM TIME-LINE, 2007-13

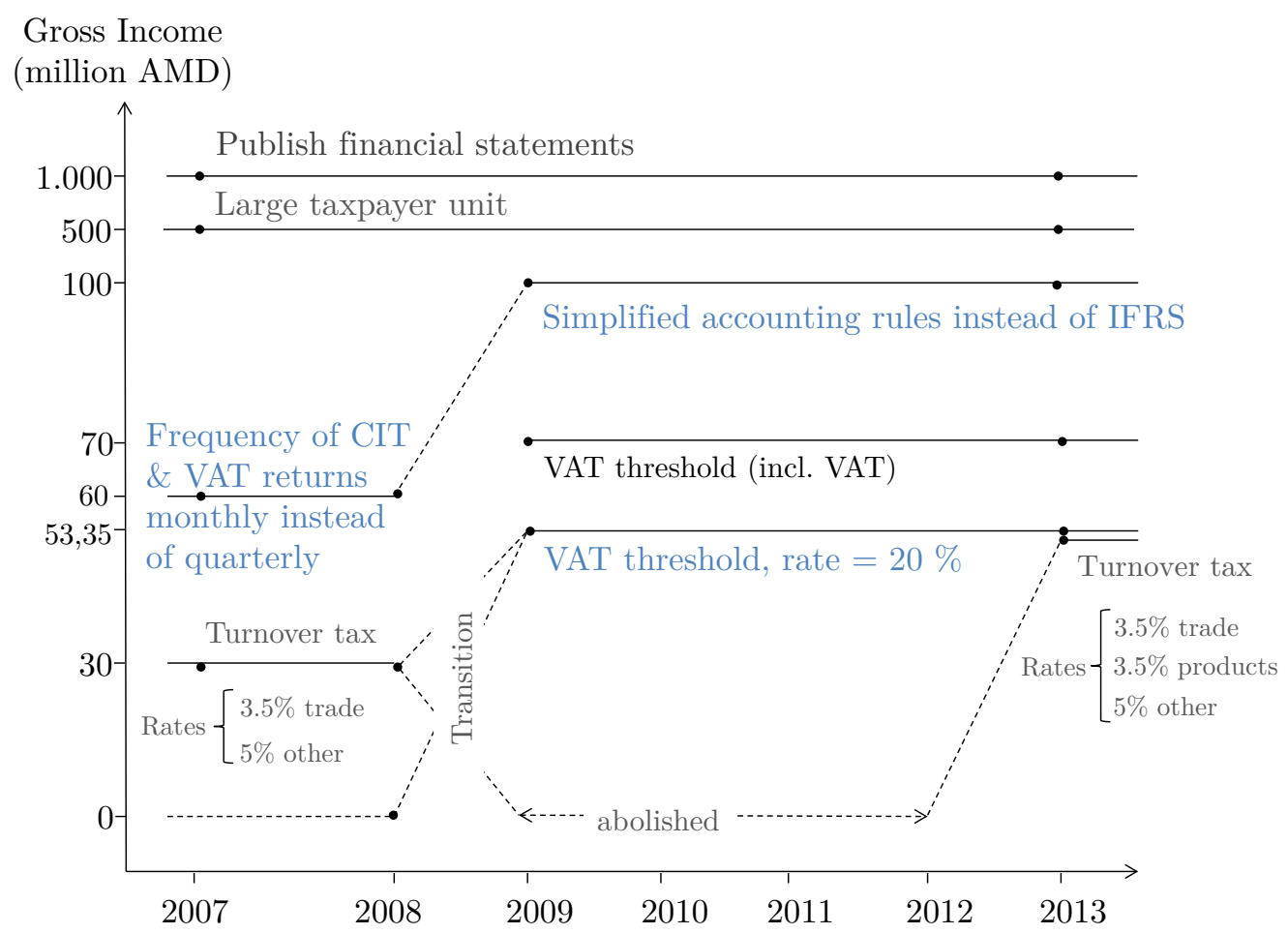

Source: Own compilation based on legal documents.

32 percent of respondents of the same survey also thought that a major reason for tax evasion is the inefficient tax administration (USAID 2014, p. 82) along with the high tax rates (32 percent of respondents) and the deteriorating economic situation (21 percent of respondents). An earlier survey finds that, indeed, these two types of taxes - VAT and CIT - were the most time consuming taxes among all taxes firms paid in 2009, with an average of about 53 and 50 hours spent annually on accounting for VAT and corporate income taxes (International Finance Corporation 2011, p. 45).

The VAT notch: Figure 2 summarizes the major reforms that took place in the Armenian corporate tax law in 2007-13. Among these we study, first, the VAT registration threshold: firms with VAT exclusive (inclusive) sales of above 58,350 (70) million AMD (or about 140,000 USD) are required to charge VAT on all sales thereby creating a notch (Republic of Armenia 2014b, Article 3, paragraph 1); firms below the threshold can voluntarily opt to register as VAT firms in which case they can also claim VAT returns. 
As described above, Armenia is an interesting case since the VAT threshold is currently one of the highest in the world, and is higher than in any OECD member country (Table A1). This level was reached after a major, almost twenty-fold, increase in 2009 which the government cited as one of the crisis prevention mechanisms (Government of the Republic of Armenia 2009).9

The administrative notch: Second, we study firms' response to an administrative size dependent threshold which aims to benefit smaller firms by creating favorable rules of tax administration for SMEs. The threshold is set at 100 million AMD of total annual gross income (60 before 2009) or about 240,000 USD. The thresholds applies to both VAT and corporate income taxes. First, firms with turnovers not exceeding the threshold are allowed to file tax returns and make the respective payments on a quarterly rather than monthly basis. Second, these small and medium-size enterprises can use simplified tax accounting procedures instead of having to comply with the International Financial Reporting Standards (Republic of Armenia 2014a, Artcile 2, paragraph 3). The lower frequency of tax returns is also applicable for firms employing not more than 5 employees independent of their income, which we can use to disentangle any potential responses to the two incentives.

Survey evidence suggests that, in the view of businesses, this threshold significantly reduced the burden of tax compliance for small firms (USAID 2014). The WB's Business Environment and Enterprise Performance Survey (BEEPS) of Armenian enterprises in 2013 also reveals a picture suggesting that this special treatment of SMEs might help reduce their tax compliance costs. Of the 100 firms covered by the survey, 50 firms have sales below the threshold and report on average corruption as an obstacle to current operations to be 0.5 points lower (on a 0-4 scale) than the average firm and 0.75 points lower than the 50 firms above the threshold.

\footnotetext{
${ }^{9}$ In 2015, the threshold for construction firms was raised further to 115 million AMD, and from 2017 announced reforms plan to decrease the general VAT threshold to 40 million AMD.
} 
Other notches: In Figure 2, we show several other features of the tax systems, which are also of potential interest, since there is not much evidence on firm response to these policy tools. We attempted to also analyze these, but could not arrive at conclusive evidence often due to data limitations. First, there is a size threshold below which firms qualify for a voluntary simple tax on turnover instead of the corporate income tax. This was set at 30 million AMD of turnover for 2007-08, abolished afterwards, then reintroduced again in 2013 at a higher level of 58,35 million AMD. The turnover tax is to replace the value added and/or the corporate tax, while in our data we only observe the corporate tax return, therefore making the study of the turnover tax not straightforward. ${ }^{10}$ Second, firms with an income of more than 500 million AMD are typically under the authority of the large taxpayer unit. This implies, for example, different enforcement rules such as higher audit rates. Although this is again an interesting and policy relevant issue, we cannot study this policy in our setting easily because of the few number of firms in this part of the size distribution of firms (there are about 250-300 firms that operate under the large taxpayer unit), but also because the tax authorities may choose to select firms into the unit which are smaller than the threshold. Instead, we refer to Almunia and Lopez-Rodriguez (2014) who study the firm-level effects of the Spanish large taxpayer unit. Third and finally, firms with turnovers exceeding 1 billion AMD are required to publish their financial statements. The low frequency of firms again prevents us from studying this threshold. The size distribution of these large firms is presented in Figure A1 of the Appendix. While there is also bunching visible, there are too few observations to estimate statistically significant effects. 
Table 1: SAmple STATISTICS

\begin{tabular}{|c|c|c|c|}
\hline By MAIN Industry & Observations & $\begin{array}{l}\text { Mean Gross Income } \\
\text { in thousand AMD }\end{array}$ & $\begin{array}{l}\text { Mean Number } \\
\text { of Employees }\end{array}$ \\
\hline Trade $(\mathrm{G})$ & 14,015 & 590,439 & 16 \\
\hline Services (I, L, M, N, T) & 11,701 & 127,149 & 23 \\
\hline Utilities (D, E, P, Q, R) & 9,553 & 394,499 & 78 \\
\hline Manufacturing (C) & 6,729 & 505,872 & 43 \\
\hline Construction $(\mathrm{F})$ & 6,724 & 292,734 & 22 \\
\hline IT (J) & 2,546 & 693,493 & 43 \\
\hline Transport (H) & 2,442 & 509,798 & 49 \\
\hline Finance $(\mathrm{K})$ & 2,196 & $1,321,816$ & 59 \\
\hline Mining (B) & 1,365 & 691,434 & 39 \\
\hline Public administration $(\mathrm{P})$ & 219 & 81,404 & 29 \\
\hline Missing & 10,999 & 59,281 & 8 \\
\hline By LEGAL InCORPORATION & Observations & $\begin{array}{l}\text { Mean Gross Income } \\
\text { in thousand AMD }\end{array}$ & $\begin{array}{l}\text { Mean Number } \\
\text { of Employees }\end{array}$ \\
\hline Limited Liability Company & 50,670 & 272,968 & 15 \\
\hline Closed Joint Stock Company & 8,883 & $1,233,848$ & 100 \\
\hline State Enterprise & 3,395 & 96,247 & 92 \\
\hline Open Joint Stock Company & 2,125 & 497,549 & 46 \\
\hline Trade Cooperative & 1,553 & 72,923 & 11 \\
\hline Local Government & 1,194 & 25,141 & 21 \\
\hline Non-Governmental Organization & 1,149 & 27,496 & 17 \\
\hline Foundation & 729 & 129,922 & 50 \\
\hline Other & 680 & 82,462 & 30 \\
\hline TOTAL & 70,378 & 376,556 & 32 \\
\hline
\end{tabular}

Notes: NACE first-letter industry-codes in parentheses.

\section{Data and Sample}

Our analysis is based on administrative data on the full population of Armenian firms that file corporate tax returns, and covers the years 2007 to $2013 .{ }^{11}$ The data are obtained from the Central Bank of Armenia. They include all the standard information from the tax returns such as gross income and deductible costs (each with their detailed items), together with information on audits and detected tax evasion, as well as some basic firm characteristics. The annual number of entities filing for corporate taxes varies between

\footnotetext{
${ }^{10}$ For a discussion of special tax regimes in transition countries, see, Engelschalk and Loeprick (2016), and for an application on small firms in Pakistan, see, Best et al. (2015).

${ }^{11}$ The sample does not cover firms which do not file corporate tax returns, such as sole-proprietorships that operate under special tax regimes for micro-enterprises. Firms that do not register for VAT but file corporate tax returns are included.
} 
Table 2: Summary STATISTiCs

\begin{tabular}{|c|c|c|c|c|c|c|}
\hline Variable & Obs. & Mean & SD & $\mathrm{P} 25$ & $\mathrm{P} 50$ & $\mathrm{P} 75$ \\
\hline \multicolumn{7}{|l|}{ Tax-items: } \\
\hline Gross Income (thousand AMD) & 70,402 & 376,446 & $4,897,106$ & 5,210 & 27,731 & 120,345 \\
\hline Annual growth of gross income & 40,307 & 0.23 & 0.96 & -0.28 & 0.03 & 0.39 \\
\hline Total deductions / Gross income & 67,344 & 0.98 & 0.78 & 0.84 & 0.93 & 0.99 \\
\hline Profit tax / Gross income & 67,271 & 0.03 & 0.91 & 0.01 & 0.01 & 0.03 \\
\hline Additional income due audits / Gross income & 8,805 & 0.06 & 0.15 & 0.01 & 0.02 & 0.04 \\
\hline Input costs / Gross income & 26,143 & 0.62 & 1.70 & 0.35 & 0.70 & 0.86 \\
\hline \multicolumn{7}{|l|}{ Firm-characteristics: } \\
\hline Number of employees & 70,161 & 32.2 & 160.6 & 2.3 & 7.0 & 20.0 \\
\hline Age of firm (years) & 90,854 & 7.28 & 5.22 & 3.00 & 7.00 & 11.00 \\
\hline \multicolumn{7}{|l|}{ Tax-audits: } \\
\hline Audits announced in t-1 (dummy) & 35,871 & 0.12 & 0.33 & & & \\
\hline Audits executed in t (dummy) & 25,564 & 0.25 & 0.43 & & & \\
\hline Duration of audits (days) & 25,564 & 3.62 & 11.43 & & & \\
\hline
\end{tabular}

Notes: The first seven variables are available over 2007-2013 and come from corporate income tax returns (item numbers of the tax return in parentheses): Gross income (C0100), total deductions (C0200), profit $\operatorname{tax}(\mathrm{C} 1300)$, Additional income due audits (C0119), input costs or deductions related to the purchase of goods (C0201), number of employees (A). Data on Annual growth of gross income and Total deductions / Gross income is trimmed at top/bottom, respectively, 5 and 1 percentiles. Age of firm was extracted from the website of the Tax Service of the Republic of Armenia in July, 2014 (taxservice.am). The audit variables - audits planned, audits executed and duration of audits - are published at the same source and are available for the years 2012 and 2013.

9,000 and 13,000 firms. Some of this variation is due to the abolishment of a simple tax on turnover for small firms in 2006-07 (that replaces the VAT and/or corporate income tax) and its re-introduction in 2013 (Figure 1).

Table 1 presents some basic statistics - frequency of firms, mean annual income and mean number of employees - per industry of the economy (top panel) and by type of firms' legal incorporation (bottom panel). The five largest industries by number of firms are trade $(20 \%)$, services (17\%), utilities (14\%), manufacturing (10\%), and construction (10\%); and the most common types of firms are Limited Liability Companies (LLCs, 71\%) and Closed Joint Stock Companies (CJSCs, 13\%). Table 2 additionally presents the full summary statistics - including the main items of the tax return, firm characteristics and information on tax audits - for the total sample. 


\section{Results}

We start by graphically studying the size distribution of firms around the VAT and administrative notches in sub-sections 3 and 4, respectively. The following sub-section 4.3 presents the bunching estimates and the according elasticities of the behavioral responses of firms based on back of the envelope calculations. In sub-sections 4.4 and 4.5, we then study the mechanisms behind these average responses, and whether the responses and mechanisms are different for heterogeneous firms.

\subsection{Response to the VAT Notch}

Figure 3 plots the frequency of firms around the VAT notch. The first vertical line is the threshold in terms of income without accounting for the VAT (58,350 thousand AMD) which applies to non-VAT firms, and the second vertical line is the threshold including the VAT (70,000 thousand AMD) applicable for VAT registered firms. Generally we are unable to detect a strong response to the VAT notch by firms paying the corporate income $\operatorname{tax}^{12}$

This result is robust when looking at the heterogeneity of response per sector (Figure 3c) and according to the quartile of the share of input costs in turnover (Figure 3d). This distinction is motivated by the reasoning that firms with a higher share of input costs have higher incentives to register in the VAT system (therefore less incentives to bunch at the notch by shifting income) because only then can they claim back their VAT inputs. Figure A2d of the Appendix demonstrates that trade firms have a much more right-skewed distribution of their input costs than, for example, construction (A2a), manufacturing (A2b), or service (A2c) firms. However, notable differences in the distribution of these different firms around the VAT notch do not emerge. This result is in line with Boonzaaier

\footnotetext{
${ }^{12}$ This evidence does not preclude that individual entrepreneurs or other types of micro firms - who do not file for corporate taxes and thus do not appear in our data - respond to the VAT. Importantly, however, the VAT notch in our sample does not necessarily interact with the margin of the decision to stay an entrepreneur or to incorporate. This is typically the case for turnover based taxes which often replace the VAT and/or corporate income taxes, and apply to the same threshold as the VAT registration threshold. Turnover taxes in Armenia, however, were abolished for the years 2008 through 2012.
} 
Figure 3: RESPONSE TO VAT NOTCH

(a) All firms

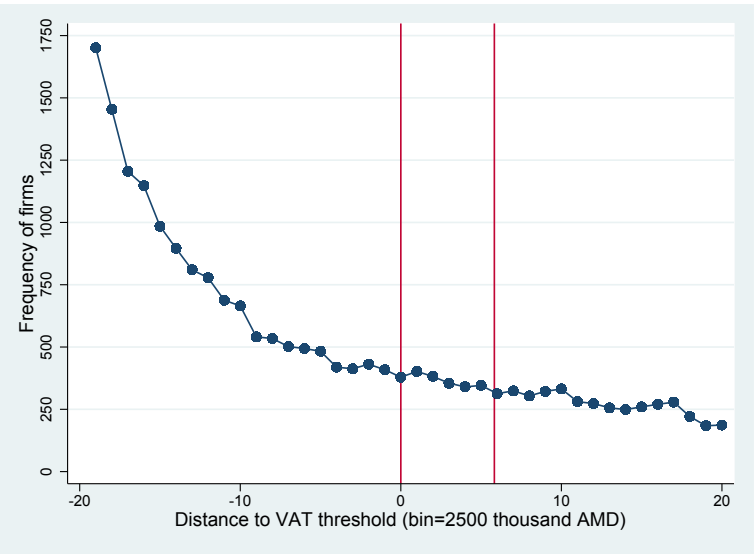

(c) By sector

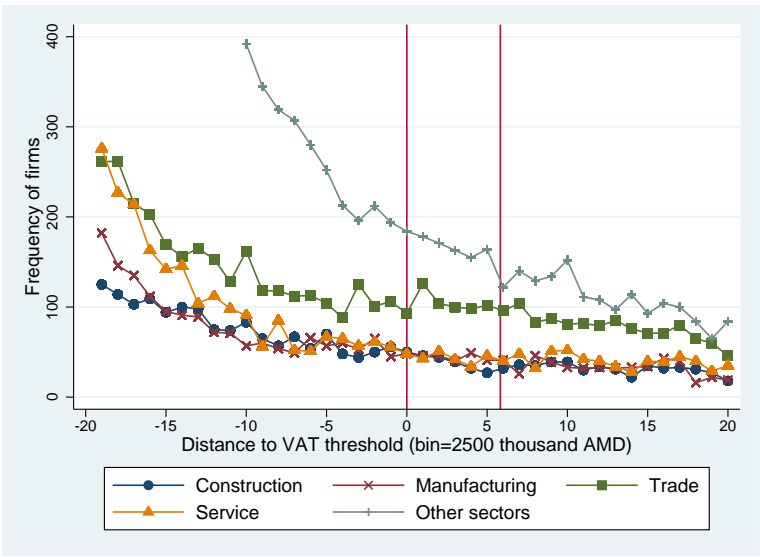

(b) By VAT registration, only 2013

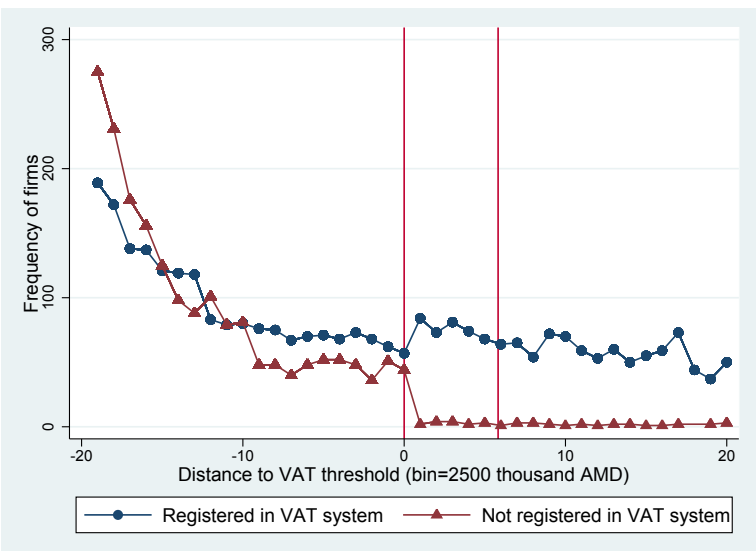

(d) By share of input costs

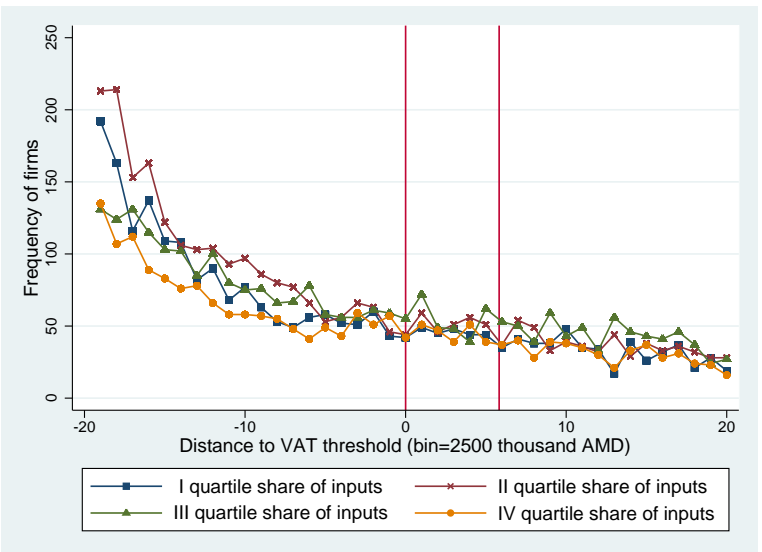

Notes: Figures plot the frequency of firms per bin around the VAT notch. The VAT exclusive and inclusive thresholds are denoted by, respectively, the first and second vertical lines. All sub-figures use data from 2009-13 other than sub-figure (b) which relies only on 2013 data since the information on the VAT registration status is available only as of July 2014 (and therefore may not be accurate if firms have (de)registered). The sectors in sub-figure (c) are aggregated using the NACE classification (first letter industry codes in parentheses: manufacturing $(\mathrm{C})$, construction $(\mathrm{F})$, trade $(\mathrm{G})$, services $(\mathrm{I}, \mathrm{L}, \mathrm{M}, \mathrm{N}, \mathrm{T})$, other (all other sectors including firms with missing industry codes). The share of inputs in sub-figure (d) refers to the ratio of deductions directly related to the purchase of goods in gross income (see also Figure A2).

et al. (2016) who show very small responses to the VAT threshold in South Africa (which also has a high threshold).

A potential explanation of this result, which is opposite to recent evidence from Japan, the UK and Finland (Onji 2009, Liu and Lockwood 2015, Harju et al. 2015), is that the VAT registration threshold in Armenia is sufficiently high so that the compliance costs of firms of this size, on average, do not outweigh their benefits (such as the right to claim 
back the tax on inputs) from registering as VAT firms. Not surprisingly, the data shows that approximately 40 percent of firms that were below the VAT threshold in 2013 have voluntarily registered for VAT (Figure 3b). In a closer neighborhood to the notch, say 10 bins before it (equivalent to 25 million AMD), there are even more voluntarily registered VAT firms than non-VAT firms. ${ }^{13}$

\subsection{Response to the Administrative Notch}

Unlike the VAT notch, we find a strong response to the administrative notch. In Figure 4a, we plot the frequency of firms over different bin sizes around the threshold (normalized to 0 ). Figure $4 \mathrm{~b}$ shows that for-profit enterprises bunch, but state owned ones do not. Figure 4c allows disentangling the incentives created by a lower frequency of tax returns and payments (which applies to firms with 5 or less employees independent of turnover) and the simplified tax accounting regime (instead of IFRS). It seems that both rules matter, but the accounting rule (i.e. the difference between small and large firms) generates a stronger response (we return to this issue below). This bunching evidence is also robust across industries (Figure 4d). In the latter we find that trade firms respond strongest to this administrative threshold, which can perhaps be explained by their higher evasion opportunities (again, more below).

Going one step further, in Figure 5 we exploit the panel dimension of our data. Since the administrative threshold was changed substantially in 2009 increasing from 60 to 100 million AMD, we can test whether firms start to (de-)bunch at the (lower) higher threshold after the reform. Figure 5 shows that this is indeed the case, and that the response is not only persistent, but is also getting stronger in time. Looking at differences in bunching also allows to relax some of the identifying assumption. We previously assumed the size distribution of firms around the threshold to be flat in absence of the notch, now it is sufficient to assume that the change in the size distribution of firms would

\footnotetext{
${ }^{13}$ Unreported probit regressions on the determinants of voluntary registrations show that these firms are on average younger, have fewer employees, and have a smaller share of input costs relative to income.
} 
Figure 4: Response to ADMINISTRATIVE NOTCH

(a) Small bins

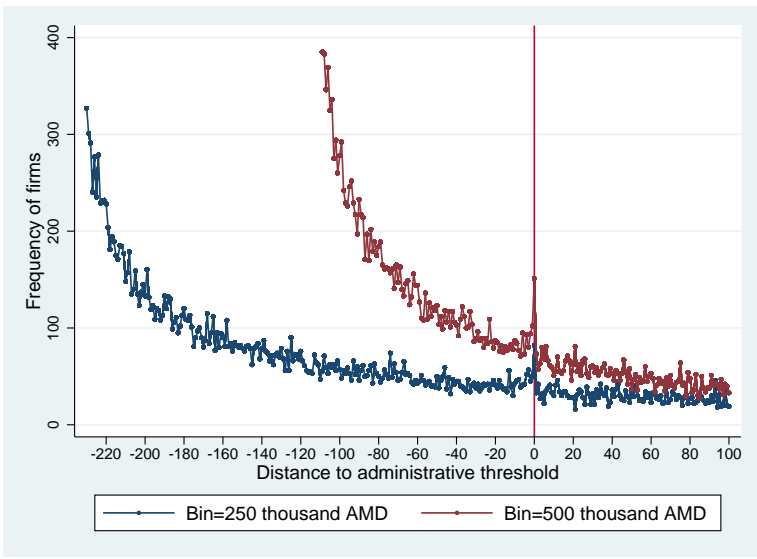

(c) By number of employees

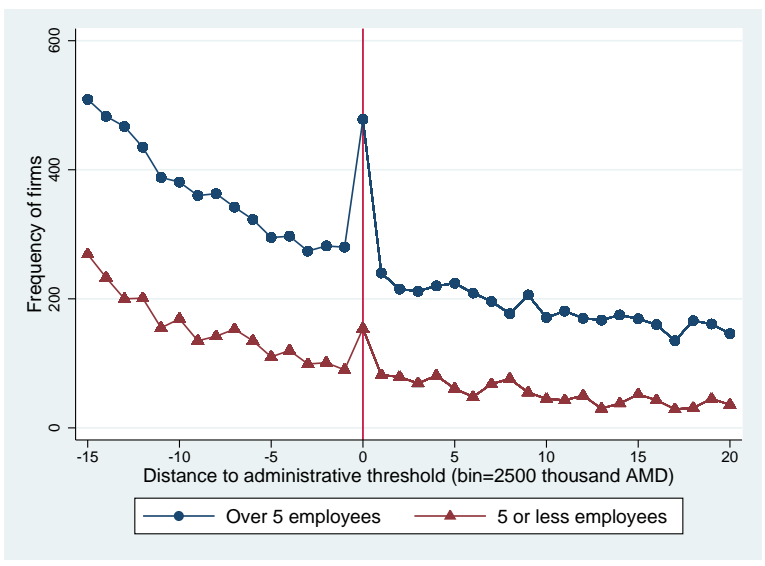

(b) For-profit vs state-owned enterprises

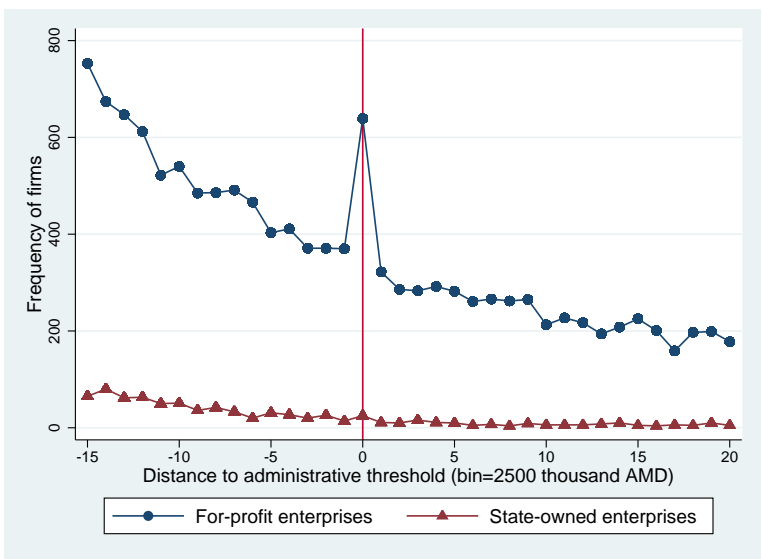

(d) By sector

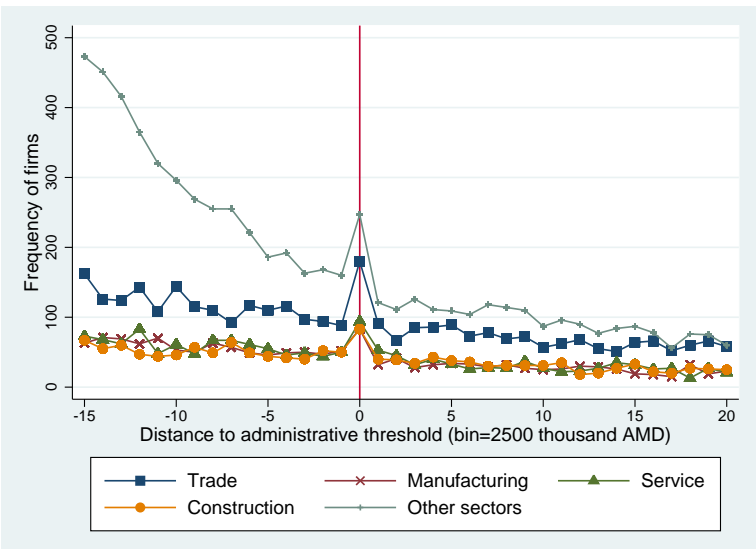

Notes: Figures plot the frequency of firms per bin around the administrative notch. The administrative threshold is normalized to 0 and is denoted by a vertical line.

have been flat in the absence of the notch. This helps to rule out several biases, such as the potential concern of overestimating the size of the firm response due to round number bunching (or other, perhaps unobservable, factors that have not changed over time).

We complement the graphical evidence by estimating probit regressions on the determinants to bunch. The results are summarized in Table A2 in the Appendix, where in columns 1-6 and 7-12 firms are defined to be "bunchers" if they are located within, respectively, a $5 \%$ and $10 \%$ window below the administrative notch. These estimates confirm the graphical evidence that bunching is persistent in a way that the bunching behavior in year $t-1$ is a significant predictor of bunching today. Furthermore, the regressions provide further descriptive evidence on the determinants of bunching behavior. The share 
Figure 5: Response to CHANGE IN ADMinistrative NOTCH

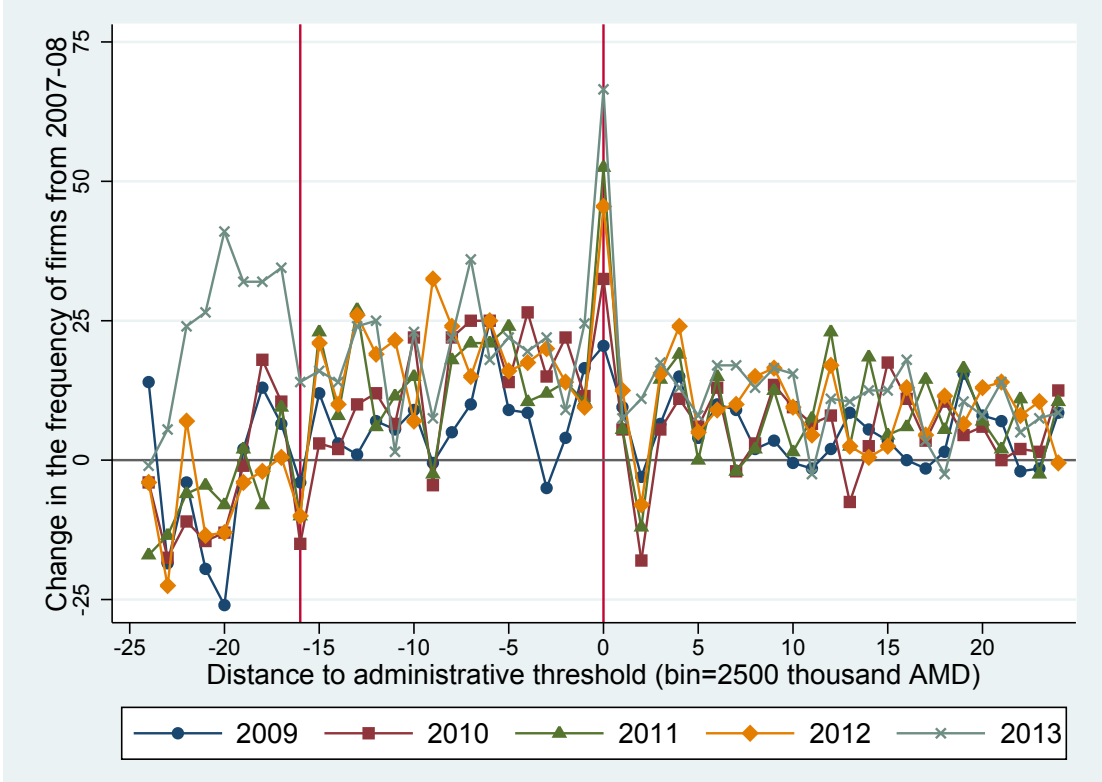

Notes: Figure plots the change in the distribution of firms over time compared to the pre-reform period (2007-08). The pre- and post-reform administrative thresholds are denoted by, respectively, the first and second vertical lines.

of remitted profit taxes (in some regressions also the total deductions) in gross income is a positive predictor for bunching behavior, albeit not consistently significant for the latter. Assuming that taxes and expenditures are similar below and above the threshold, this result suggests that bunching at the threshold occurs through income underreporting (we investigate this further below). Third, the announcement in year $t-1$ of an audit in the coming year reduces the probability of firms to bunch (columns: 4 and 10).

\subsection{Bunching Estimate at the Administrative Threshold}

Next we follow the recent literature on bunching (Saez 2010, Chetty et al. 2011, Kleven and Waseem 2013) to estimate the size of the response at the administrative threshold. ${ }^{14}$ Under the assumption that firms have smooth and heterogeneous preferences over gross income $y$, firms would locate themselves smoothly along the gross income distribution in the absence of notches. When introducing the (administrative) notch, firms below or directly at the threshold do not change their behavior. Firms in a certain area above the

\footnotetext{
${ }^{14}$ Kleven (2016) provides a review of the bunching method and we focus on the key aspects for brevity.
} 
notch have the incentive to relocate to the notch - either by generating less income or by underreporting it.

We estimate the excess mass at the notch following the bunching literature in three steps. First, we center the gross income distribution such that the threshold is exactly at zero, and group firms into small bins. Second, we estimate the counterfactual density (how the distribution would have looked in the absence of bunching at the notch) by fitting a flexible polynomial function to the observed distribution, excluding the area $\left[y_{L} ; y_{H}\right]$ around the notch threshold point from the observed distribution. ${ }^{15}$ Third, we estimate the excess bunching by relating the actual number of firms $c_{i}$ close to the threshold within the interval $\left[y_{L} ; y^{*}\right]$ to the estimated counterfactual density $\hat{c}_{i}$ in the same region:

$$
\hat{b}=\frac{\sum_{i=y_{L}}^{y^{*}}\left(c_{i}-\hat{c}_{i}\right)}{\sum_{i=y_{L}}^{y^{*}}\left(\hat{c}_{i} / N_{i}\right)}
$$

where $N_{i}$ is the number of bins within $\left[y_{L} ; y^{*}\right]$. As it is common in the literature, we calculate standard errors for all estimates using a bootstrap procedure.

Figure 6a shows that the excess mass of firms bunching at the threshold is economically large and statistically significant. For the full sample, we find an estimate of the excess mass below the threshold of 1.57. Figure A3 in the Appendix provides with sensitivity tests of this estimate of the excess mass to the selection of the excluded region (a) and to the choice of the polynomial when fitting the counterfactual distribution (b). These tests show that the estimate of the excess mass is fairly robust across both dimensions.

In Figures 6 b \& c, we differentiate between firms with 5 or less employees and those with more in order to disentangle the effects of simplified accounting rules from the effects of the change in the frequency of filing. Firms with 5 or less employees qualify to use the simplified accounting rules independent of their income, therefore any response of smaller

\footnotetext{
${ }^{15}$ Due to imperfect control and uncertainty about gross income, it is likely that we do not observe sharp bunching exactly at the threshold but rather a cluster of firms in a region below it. As is common in the literature, we determine the lower and upper limits of the excluded regions $\left(y_{L}\right.$ and $\left.y_{H}\right)$ based on visual inspection of the distribution as the point in the distribution where the bunching behavior begins and ends. In Figure A3, we then provide sensitivity tests of the estimate of excess mass to the selection of the excluded region.
} 
Figure 6: Bunching estimate AT ADministrative NOTCH

(a) Full sample

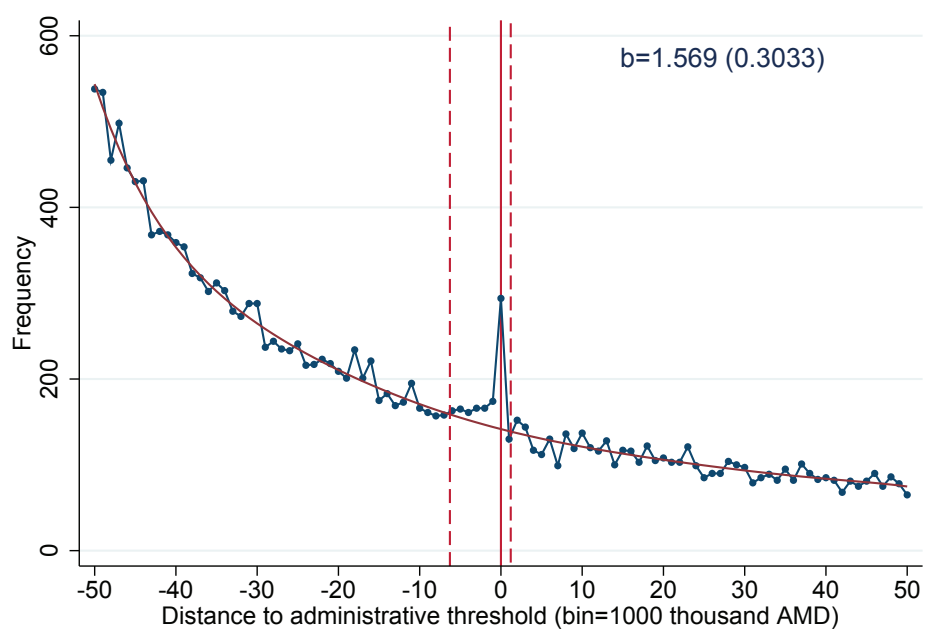

(b) Firms with 5 or less employees

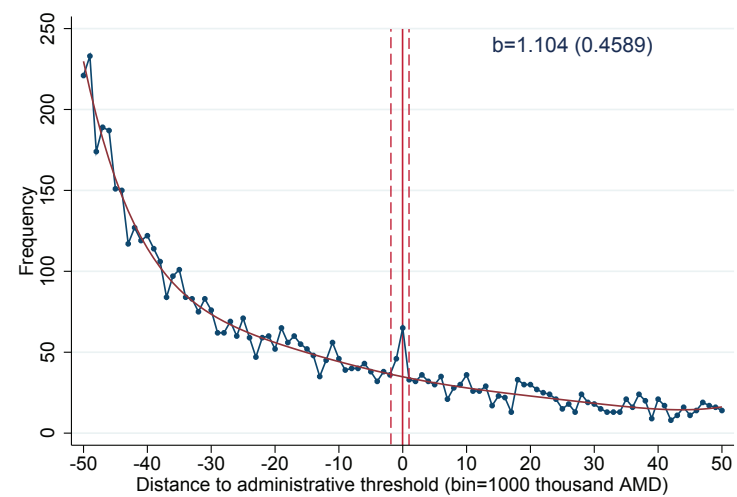

(c) Firms with over 5 employees

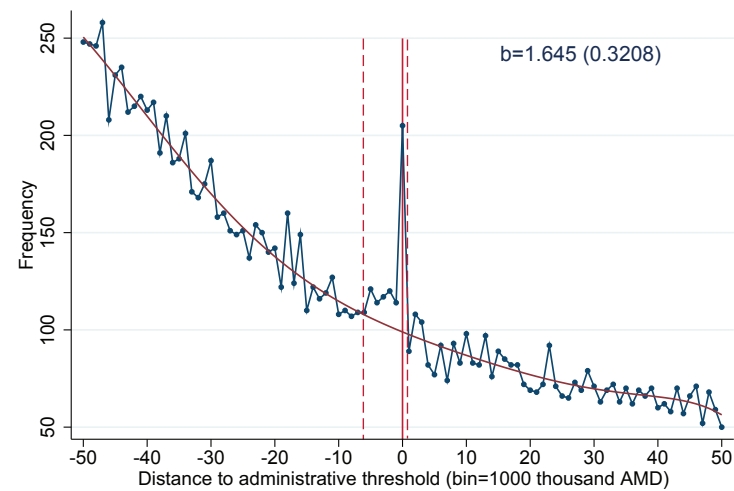

Notes: Figures plot and estimate the size of bunching around the 0-normalized administrative threshold (i.e., the bunch-point) using the method developed by Chetty et al. (2011). The bunching estimate is reported in the top right corner for every sub-figure with standard errors in parenthesis. The counterfactual distribution is estimated by fitting a polynomial of the 7th degree, and by considering 15 (50) bins on the left and right sides of the bunch point where a bin equals 1000 thousand AMD. The bunching windows on the left and right sides of the bunch point are denoted by dashed vertical lines.

firms to the administrative threshold should be driven by the frequency of filing rules. Larger firms respond more strongly than smaller ones (1.65 vs. 1), implying that the international accounting rules trigger larger responses than the frequency of filing alone. Similar to the sensitivity tests of Figure A3, in Figure A4 we study the robustness of the bunching estimate separately for accounting rules and for frequency of filing. The response to the change in the frequency of filing is relatively small and is not consistently significant across the selection of the excluded region. 
The excess mass can serve as a sufficient statistic to calculate an elasticity (Saez 2010, Kleven and Waseem 2013). However, this is not straightforward, since for an elasticity estimate at the administrative threshold one needs estimates of both the amount of compliance costs and the change of compliance costs at the threshold. Regarding the former, Eichfelder and Vaillancourt (2014) provide a survey of such estimates for many countries. Armenia, however, is not included. For OECD countries, they report average compliance costs of firm taxes between 0.4 and $3.4 \%$ of turnover for SMEs. The estimates for less developed countries such as South Africa or Ukraine are somewhat higher. The authors also find that about two thirds of the compliance costs are due to accounting rules and of these, another two thirds are due to financial accounting regulations. Based on a taxpayer survey in Armenia, International Finance Corporation (2011) estimates tax compliance costs to be highly regressive ranging from about $18 \%$ of gross income for micro firms to about 1\% for medium-sized firms. Coolidge (2012) presents further survey based estimates of tax compliance costs in developing countries. Given these estimates we assume the share of compliance costs in total gross income to be between $2.5 \%$ and $7.5 \%$. As to the change of compliance costs at the threshold, and again as a rough approximation, we rely on DeGeorge et al. (2012) who quantifies that the adoption of IFRS increases observable expenses on audits, on average, by around 23\%. Also, comparing the 50 firms that are below and above the threshold from the BEEPS survey of 2013 (see Section 2), suggests that the difference in self-reported compliance costs among these two groups might be around $15 \%$ on average. Based on this, we assume four values (between 5\% and 30\%) for the change in compliance costs. Together with the three different values for the share of compliance costs, we have 9 different scenarios for the back of the envelope calculation of elasticities as shown in Panel A of Table 3.

The resulting elasticities vary between 0.13 and 2.35. Using a change in compliance costs of 20\% (DeGeorge et al. 2012) and a share of compliance costs in gross income of 5\% (Eichfelder and Vaillancourt 2014) would yield a baseline estimate for the elasticity with respect to compliance costs of around 0.4 - which would be comparable to tax 
Table 3: BACK OF THE ENVELOPE ESTIMATES

\begin{tabular}{|c|c|c|c|}
\hline \multicolumn{4}{|c|}{ PANel A: Estimate of Elasticity } \\
\hline \multirow{2}{*}{$\begin{array}{l}\text { Change of compliance } \\
\text { costs at the threshold }\end{array}$} & \multicolumn{3}{|c|}{ Share of compliance costs in gross income } \\
\hline & $2.5 \%$ & $5 \%$ & $7.5 \%$ \\
\hline $5 \%$ & 0.785 & 1.569 & 2.354 \\
\hline $10 \%$ & 0.392 & 0.785 & 1.177 \\
\hline $20 \%$ & 0.196 & 0.392 & 0.588 \\
\hline $30 \%$ & 0.131 & 0.262 & 0.392 \\
\hline
\end{tabular}

Panel B: Estimate of Change of COMPliance Costs at the threshold

\begin{tabular}{|c|c|c|c|}
\hline \multirow[b]{2}{*}{ Elasticity } & \multicolumn{3}{|c|}{ Share of compliance costs in gross income } \\
\hline & $2.5 \%$ & $5 \%$ & $7.5 \%$ \\
\hline 0.50 & $7.8 \%$ & $15.7 \%$ & $23.5 \%$ \\
\hline 1.00 & $3.9 \%$ & $7.8 \%$ & $11.8 \%$ \\
\hline 1.50 & $2.6 \%$ & $5.2 \%$ & $7.8 \%$ \\
\hline 2.00 & $2.0 \%$ & $3.9 \%$ & $5.9 \%$ \\
\hline 2.50 & $1.6 \%$ & $3.1 \%$ & $4.7 \%$ \\
\hline
\end{tabular}

elasticities for developed countries (see, e.g., Devereux et al. 2014, who find an elasticity of 0.29 for the UK). Unfortunately, we do not have a direct estimate of a tax elasticity for Armenia. However, Waseem (2016), for example, estimates an intensive-margin elasticity for SMEs in Pakistan to be around 2, that is an order of magnitude larger than estimates for richer countries. An elasticity of such a magnitude would be in line either with a lower change in the compliance costs at the threshold, or a higher share of compliance costs in gross income, or both. To shed some more light on this, in a second approach, we assume a value for the elasticity and calculate the implied change of compliance costs at the threshold. We assume a wide range of elasticities between $0.5 \% \& 2.5 \%$, and display the corresponding estimates for the change of compliance costs in Panel B of Table 3. The resulting values vary between $1.7 \%$ and $23.5 \%$. Using an elasticity of 2 as for Pakistan (Waseem 2016) and a share of compliance costs in gross income of 5\% (Eichfelder and Vaillancourt 2014) would yield a 3.9\% change in compliance costs at the threshold. While we cannot give exact estimates for the elasticity and nor for the change in compliance 
costs, we believe these back of the envelope calculations provide some insights about the range of plausible values.

\subsection{Do Firms Bunch Through Tax Evasion?}

One advantage of our study is that we are able to make use of audited tax returns to study the mechanisms of income shifting by firms. The question is whether the response of firms to the administrative threshold that we have found works through real response in supply or through income underreporting.

\section{Figure 7: Detected tax EVASION}

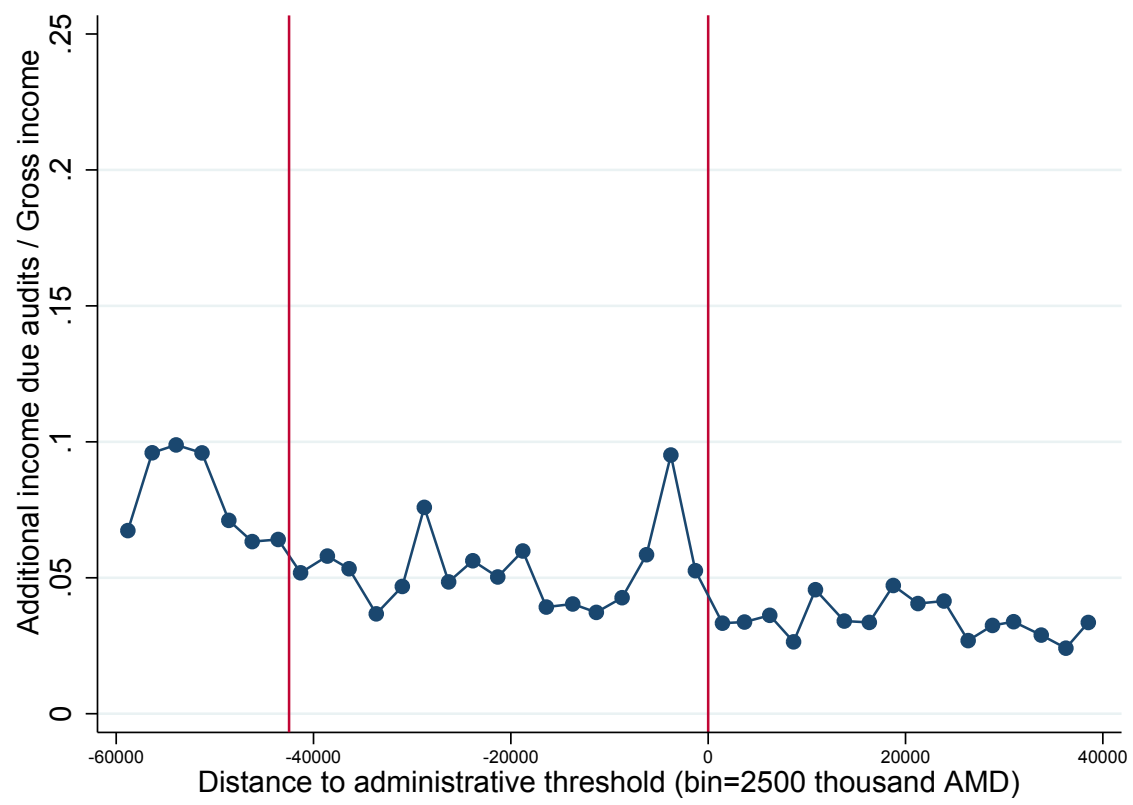

Notes: Figures plot the additional unreported income detected during audits as a share in gross income per bin. First and second vertical lines denote, respectively, the VAT and administrative thresholds.

In Figure 7, we plot the additional income that was detected by the tax authorities during audits averaged across bins. It demonstrates a spike in detected tax evasion just below the administrative threshold. The size of detected evasion is very large at about 10 percent of gross income, and is about double the average evasion rate further away from the threshold. This evidence suggests that the response of firms is at least partly driven by income underreporting. However, in order to arrive at an estimate of how much of the 
total bunching response is driven by underreporting relative to a real response, we need to make some assumptions or restrictions on the sample.

First, we start with back of the envelope calculations. For this, we need an assumption on from which part of the distribution the bunching firms come from. The average bunching firm is located one bin before the threshold. The difference in underreporting between bunching and non-bunching firms is 5 percent on average. 5 percent of gross income around the threshold (100 million AMD) corresponds to two bins $(2 \times 2.5$ million AMD). Hence, if we were to assume that the average bunching firm would belong to one bin above the thresholds under full compliance, this back of the envelope approach would yield that, on average, the behavioral response is entirely driven by income underreporting.

Second, we can study how the notch distorts the total amount of production. Figures 8 a, b \& c plot the total amount of, respectively, gross income, deductions (and their composition) and detected income due audits for all firms in each income bin around the administrative notch. The figures show, quite clearly, the amount of additional income and deductions in response to the notch. The amount of total income around the threshold is about 30 percent more than that further away from the threshold (sub-figures 8a), whereas the same ratio for total detected income due audits is about twice as large (sub-figures 8c). This comparison reaffirms our interpretation that the bunching firms have much higher evasion rates. Also, looking at the composition of income and deductions may give additional hints on the types of items of the tax return that are perhaps easier manipulated in response to the notch: reported income from sales of goods and, symmetrically, deductions for related purchases.

Third, we can restrict the analysis to audited firms and study how the bunching response differs for reported income versus total income (which additionally includes the income detected during audits). If the bunching response were driven by tax evasion, we should find a rightward shift of the distribution and a lower bunching rate at the threshold after accounting for the amount of underreported income detected during au- 
Figure 8: TOTAL SIZE OF THE RESPONSE

(a) Total gross income

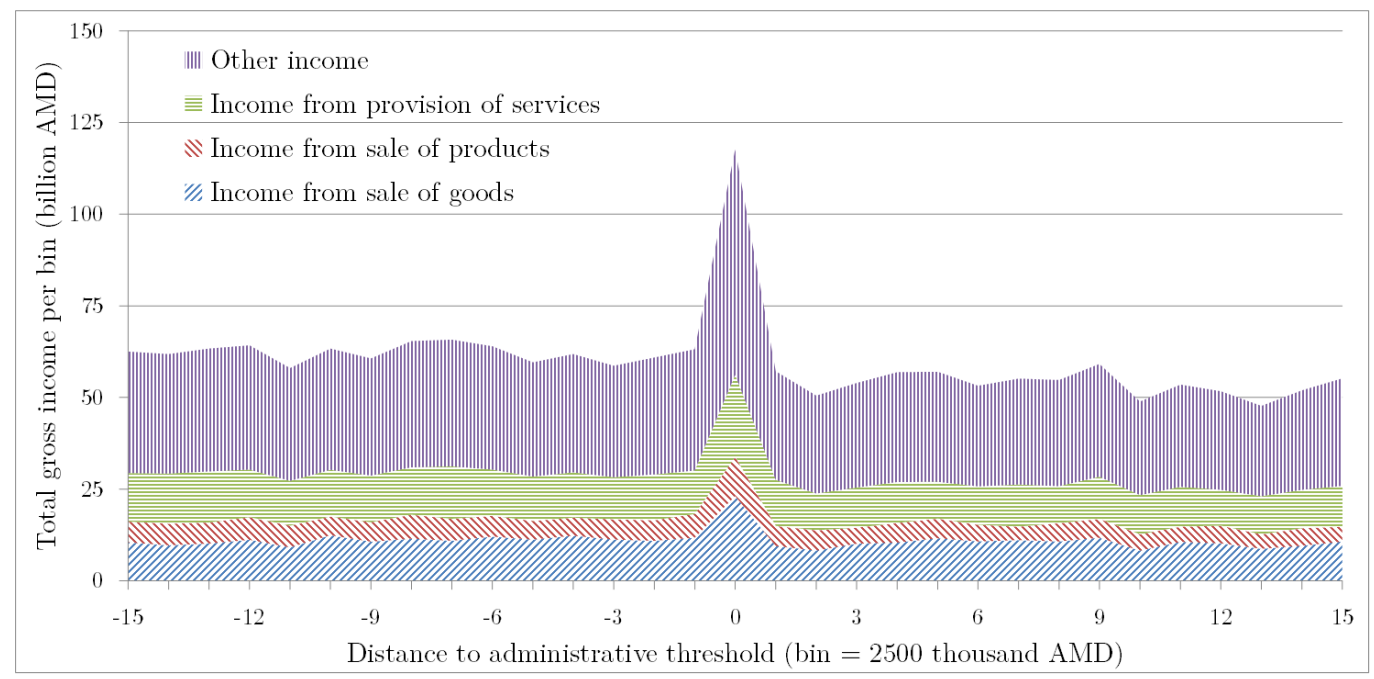

(b) Total deductions

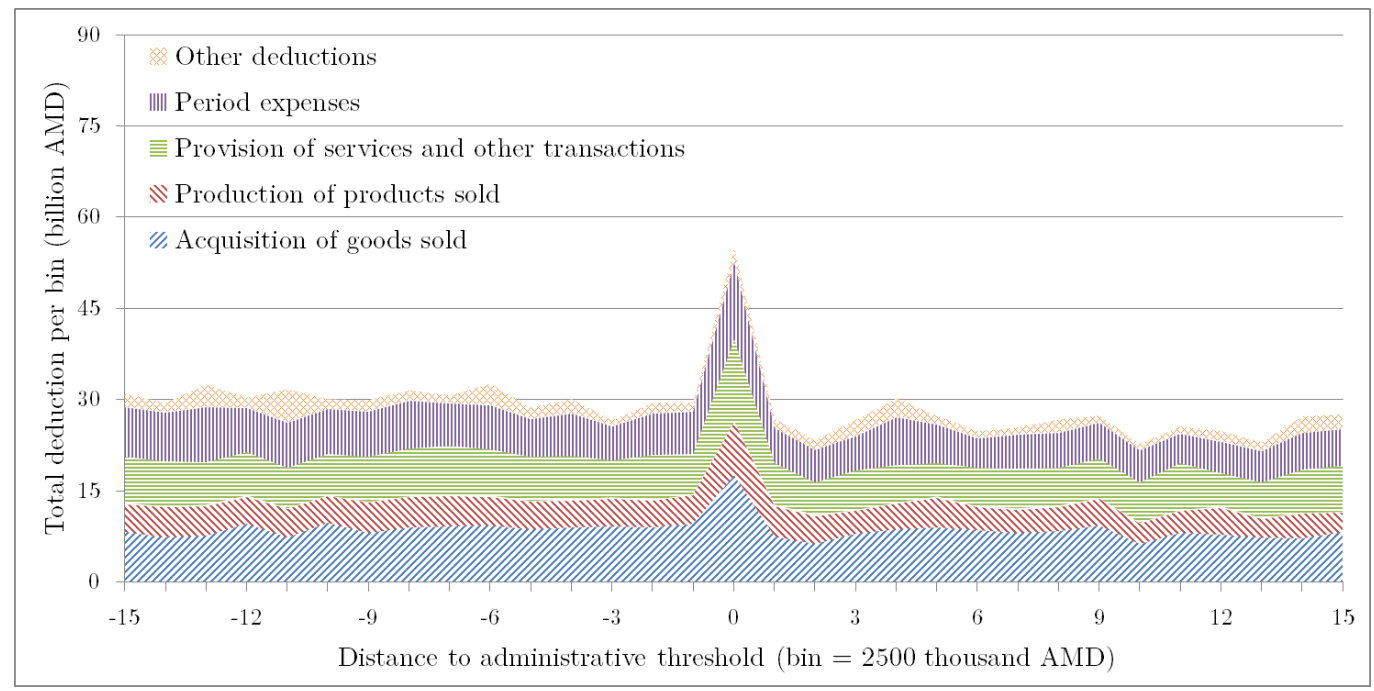

(c) Total Detected income Due audits

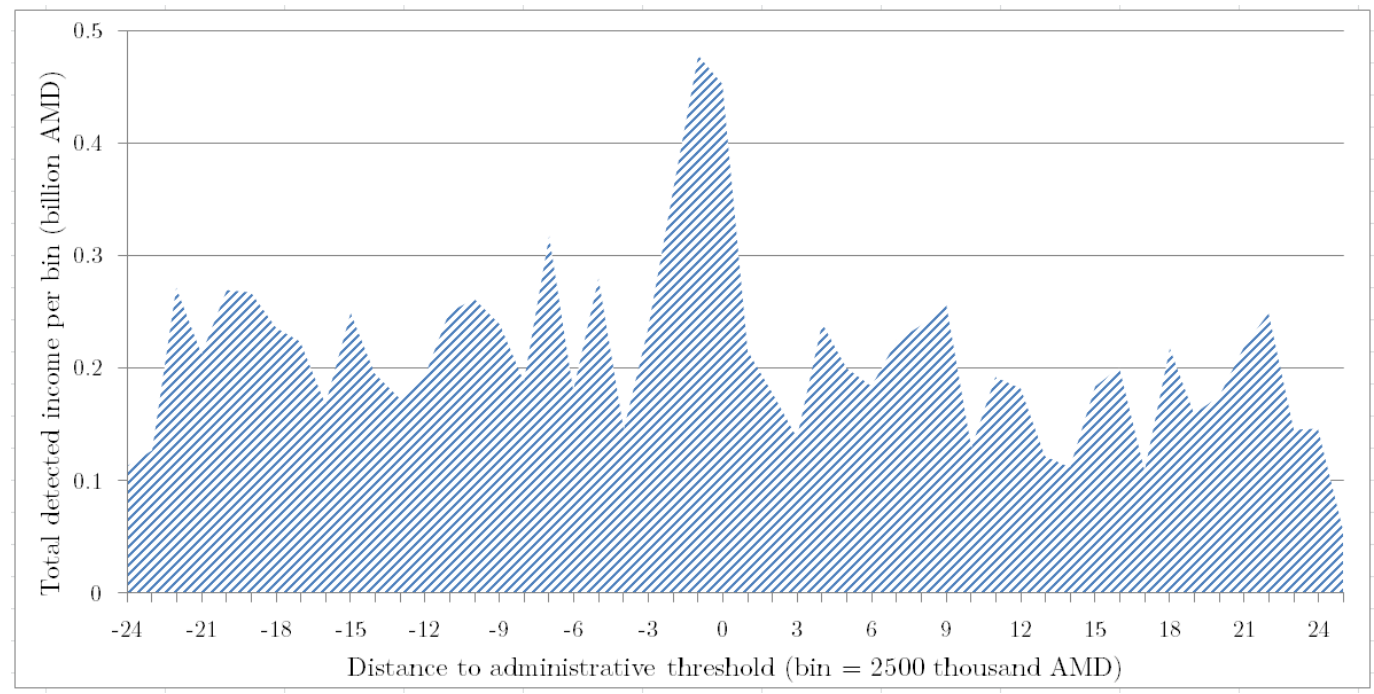

Notes: Sub-Figures (a), (b) and (c) plot the total amount of, respectively, gross income, deductions and detected income due audits per bin around the administrative notch. Income and deduction categories correspond to the following items in the tax return, in sub-figure a (from bottom to top): C0101, C0102, C0103, all else; in sub-figure (b): C0201, C0202, C0203, C0210, all else; and in sub-figure (c); C0119. 
Figure 9: BunCHING BY REPORTED AND TOTAL INCOME OF AUDITED FIRMS

(a) Reported income

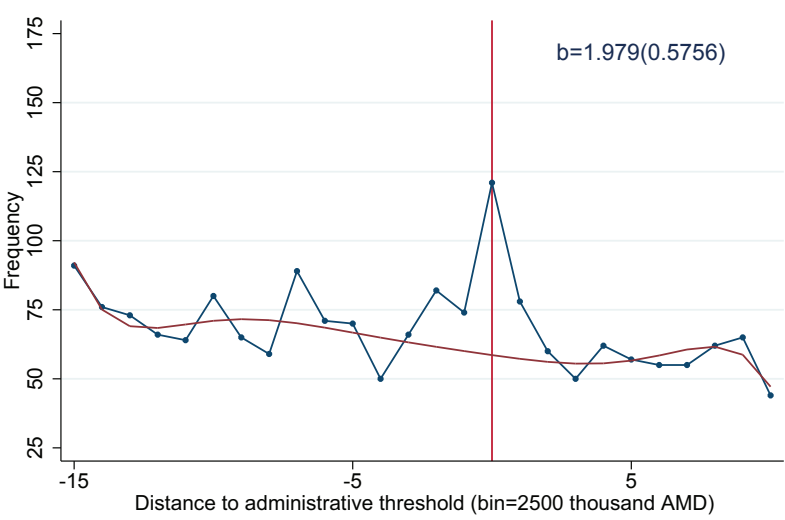

(b) Total income (reported and detected)

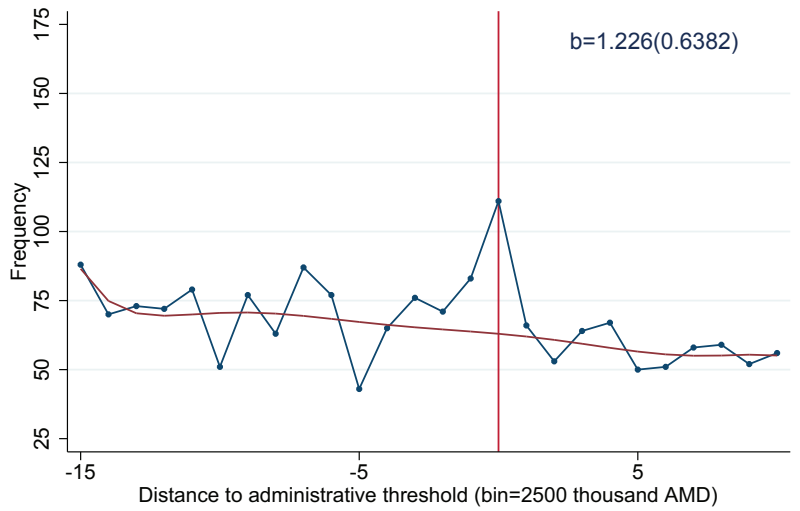

Notes: Figures present bunching estimates at the administrative threshold similar to Figure 6 . The sample is restricted to audited firms. Sub-figures (a) \& (b) plot the density of firms, respectively, by reported income and by total income which additionally includes the income detected during audits.

dits. Consistent with this prediction, in Figure $9 \mathrm{a} \& \mathrm{~b}$ we see that the excess mass of firms by reported income is around 60 percent larger than that by total income. Under full detection and absent any real responses, we should expect a smooth distribution of true income. However, the much smaller but significant excess mass of firms after audits in Figure 9b may still be due to non-detected evasion responses, since tax authorities can rarely reach full compliance even by extensive audits. The difference in the estimated excess mass of firms by reported income and by total (including detected) income - which is around 60 percent - is a lower bound estimate of the tax evasion response.

\subsection{Response and Evasion by Heterogenous Firms}

To exploit any potential heterogeneities in firm response, we divide the sample according to whether firms are growing or shrinking (defined as those reporting higher or lower income in year $t$ compared to year $t-1)$. The argument is that size dependent tax (and other) policies that favor SMEs may distort the incentives of firms to grow beyond such thresholds. These regulations are often held responsible for the empirical regularity of a "missing middle" which can be observed in the size distribution of firms of some 
Figure 10: Response By Heterogeneous FIRMS

(a) Growing firms

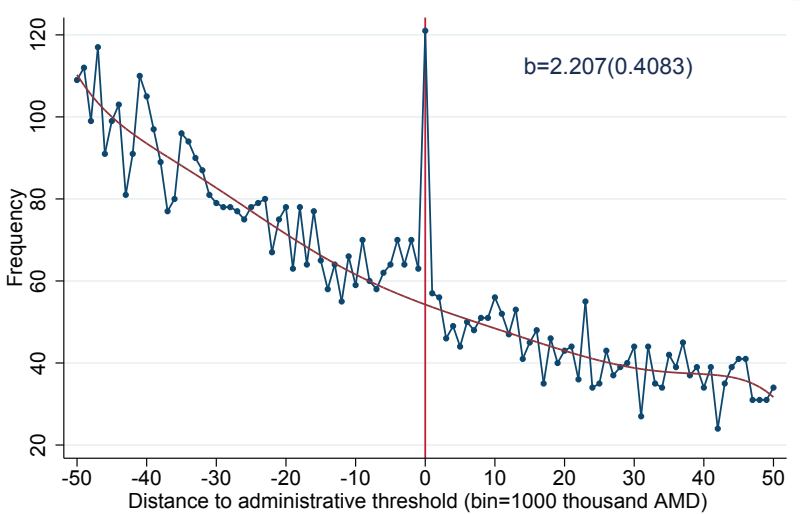

(c) Manufacturing, Construction \& Mining

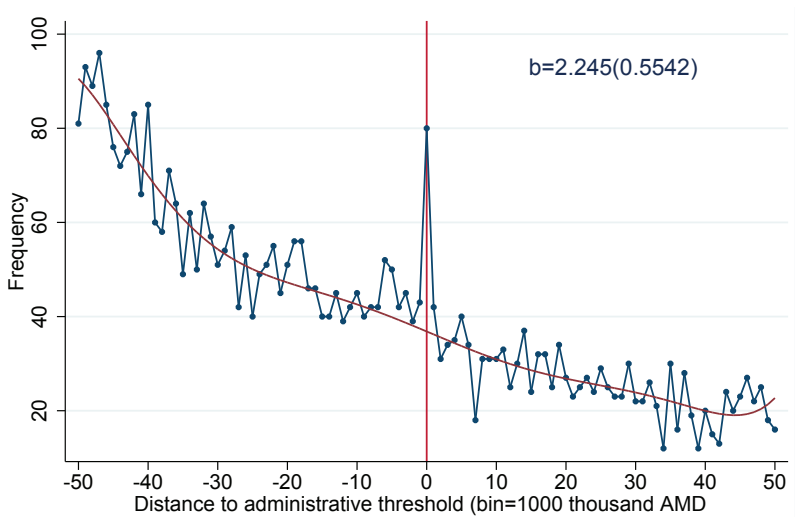

(e) Trade \& Transport

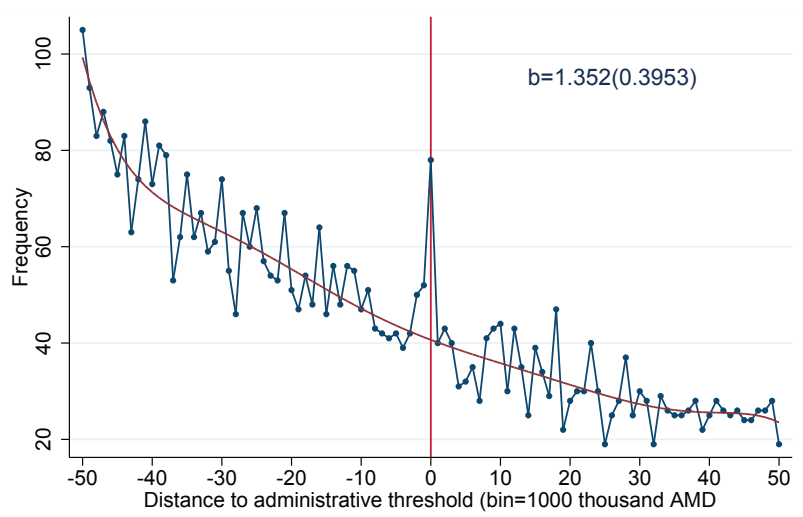

(b) Shrinking firms

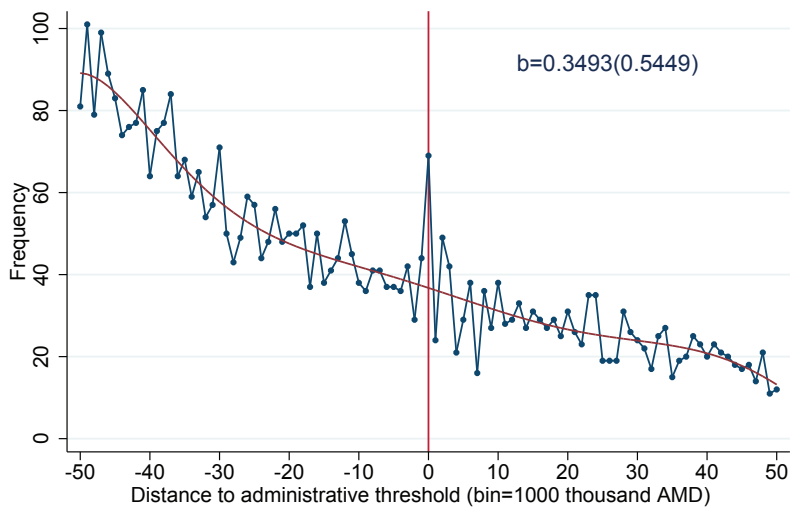

(d) Services

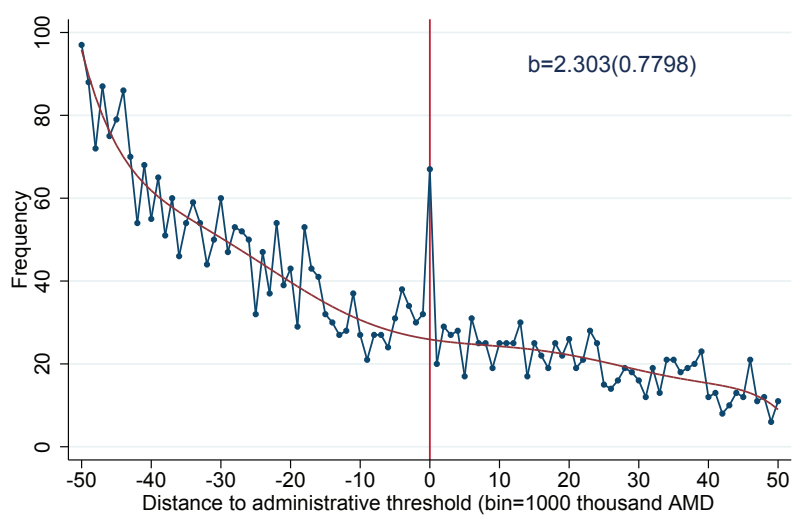

(f) Public Administration \& Utilities

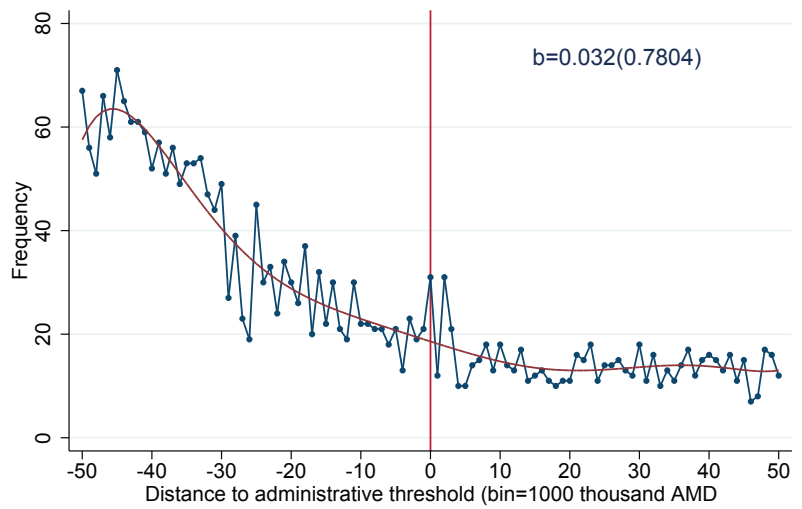

Notes: Figures present bunching estimates at the administrative threshold similar to Figure 6(a). In sub-figures (a) \& (b) the sample is split between, respectively, growing and shrinking (b) firms (which are defined as those reporting, respectively, higher or lower gross nominal income in year $t$ compared to year $t-1$ ). In sub-figures (c) to (f) the sample is split between four main industries defined for each sub-figure. 
Figure 11: DeteCted tAX EVASION By HeterogenEOUs FIRMS

(a) Growing v.s. shrinking firms

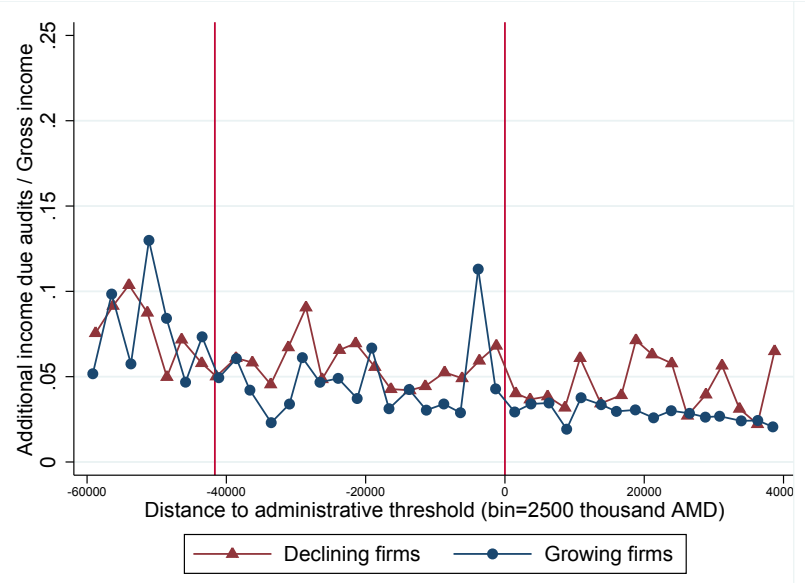

(b) By industry

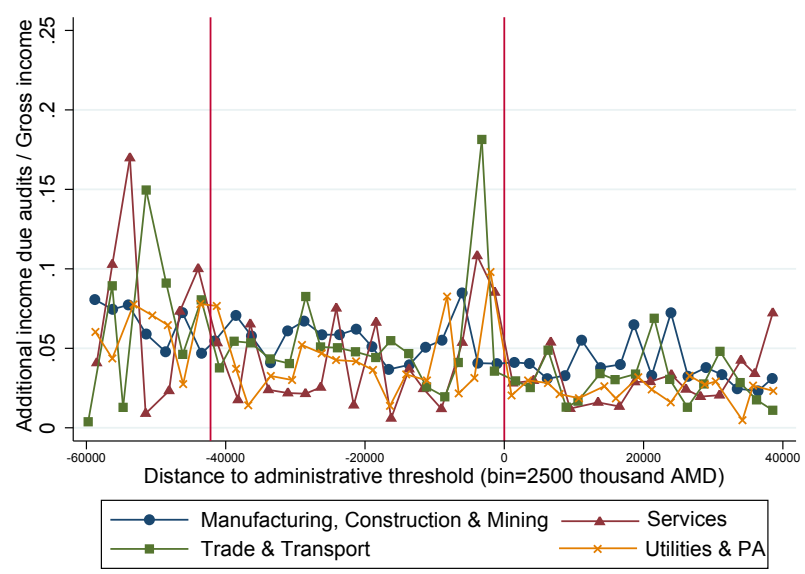

Notes: Figure plots the additional unreported income detected during audits as a share in gross income per bin around the VAT and administrative thresholds (respectively, first and second vertical lines). The sample is split between growing and shrinking firms (sub-figure a), and among main industries (sub-figure b).

countries. ${ }^{16}$ Figure 10 shows that growing firms respond strongly at the administrative notch (sub-figure 10a), while, as expected, we do not find statistically significant bunching evidence for shrinking firms (sub-figure 10b).

We also study heterogeneous responses by industry in Figure 10. As expected, firms in the industry that we broadly call Public Administration \& Utilities (includes NACEcodes: D,E, P, Q, \& R) are the only group of firms for which we do not find evidence of bunching. Such absence of bunching by declining firms and public administration firms acts as a placebo test of sorts on both of the results that firms respond to the administrative notch and they do so by income underreporting.

Another exercise is to extend the results of Figure 7 on the amount of detected evasion for both growing and shrinking firms, and for firms in different industries. By plotting the mean amounts of the size of detected evasion per bin separately for growing and shrinking firms in Figure 11(a) we additionally show that the response can be, again, largely explained by the underreporting behavior of growing firms. Owing to the reduced number of observations the data gets noisy when studying audited firms by sector;

\footnotetext{
${ }^{16}$ See, e.g., Dharmapala et al. (2011). Hsieh and Olken (2014), however, argue that this may not be the case.
} 
however, Figure 11(b) provides suggestive evidence that evasion rates and opportunities maybe higher for firms operating in some industries. These patterns are consistent with our earlier results of Figures $4 \& 10$.

\subsection{Endogeneity and Effects of Audits}

The finding of higher detected evasion below the thresholds could be driven by endogenous selection of firms. For instance, tax authorities could optimize their enforcement strategies by also responding to notches and kinks of the tax system where firms' incentives to evade change discontinuously.

Figure 12: Probability AND DURATION OF AUdits

(a) Probability of audits

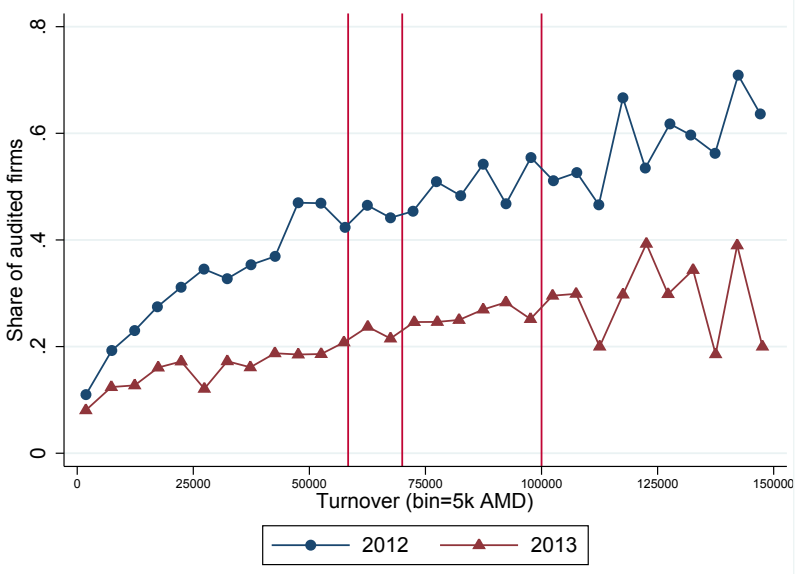

(b) Duration of audits

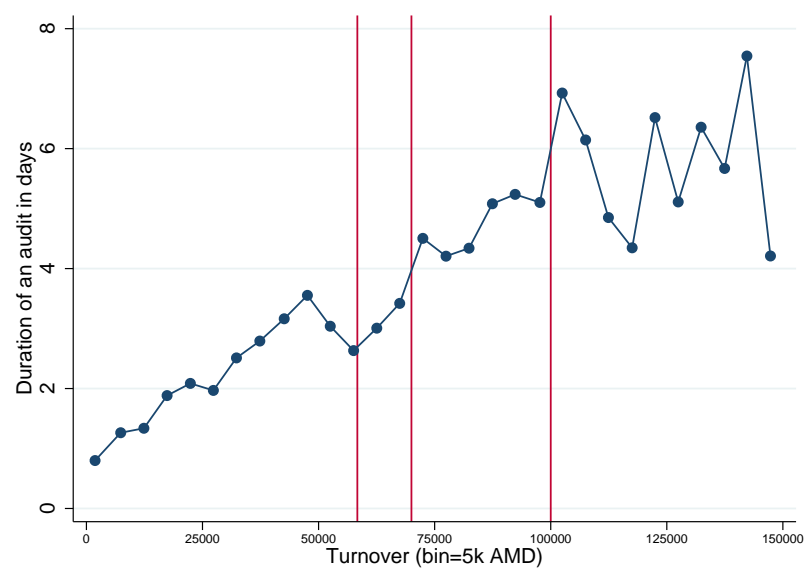

Notes: Sub-figure (a) plots the share of audited firms per bin and year, and sub-figure (b) plots the mean duration of these audits. the first, second and third vertical lines denote, respectively, the exclusive and inclusive VAT and administrative thresholds.

Figure 12a shows that this is not likely to be the case. Firms located just below the notch, on average, do not get audited more frequently. This suggests that, first, our tax evasion explanation of firms' bunching behavior is not driven by endogenous audits and, second, that tax authorities could make their audit strategy more efficient by targeting firms which have higher incentives to evade. Back of the envelope calculations show that the detection of underreported income solely by firms located at the administrative notch (which amount to less than 1 percent of all firms) could recover income of as much as 
$10 \%$ of 2013's budget deficit. We also demonstrate an increase in the duration of audits after the administrative notch in Figure $12 \mathrm{~b}$. This may be due to the administrative complexities created by more frequent tax returns and more stringent accounting rules which create additional difficulties for firms as well as for tax authorities.

In a final exercise, we study whether audits have some implications for firms' reporting behavior. Such an analysis is, of course, heavily constrained by the likely non-randomness of audits. However, in an event study design, we can exploit the dynamic structure of the data to study whether audits are correlated to firms' pre and post treatment outcomes.

In Figure 13, we find that audits mostly do not correlate with past outcomes, that is, after controlling for a firm's observable characteristics and several fixed effects (industry, legal form, region, year, and firm), its reporting behavior in years $t-2$ and $t-1$, on average, does not significantly affect the likelihood of an audit in year $t$. However, in year $t$, audits significantly increase firm's reported income by an average of about 20 percent (sub-figure 13a). This positive effect persists after the audit, but declining in size and reaching an increase of around 10 percent in reported income two years following the audit.

Firms are likely to evade taxes both by underreporting of income and overreporting of costs. However, it seems that audits effectively target only the underreporting of income by increasing income, while the opposite holds for deductions. That is, interestingly, the audit driven increase in reported income is partly compensated by an increase in reported deductions (sub-figure 13b). Quantitatively, every additional dollar of reported income in years $t, t+1 \& t+2$ is matched by, respectively, $0.68,0.81 \& 0.77$ dollars of additional deductions. This result is line with Carrillo et al. (2016), who show that firms in Ecuador respond to randomized threat-of-audit letters by increasing both reported income and reported costs at around the same rate. In balance, the profit tax liability in our sample increases much more in the year of an audit than in the two following years (sub-figure 13c), while the effective tax rate is not significantly affected by an audit (sub-figure 13d). 
Figure 13: EfFECTS of AUdits ON FIRM REPORTING OVER TIME

(a) Ln Reported Income (before audits)

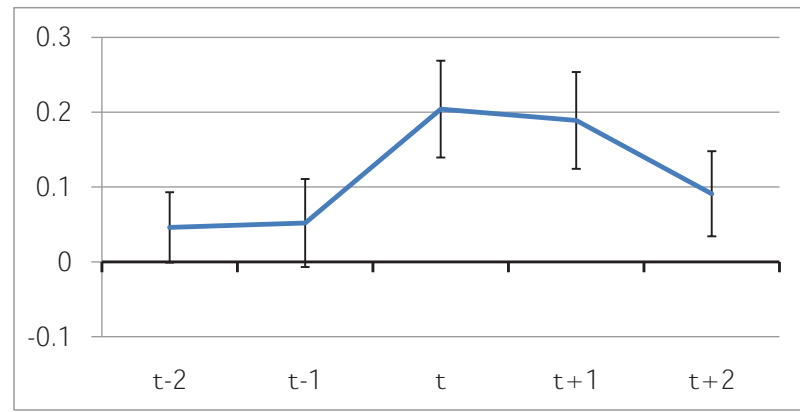

(c) Ln Profit Tax Liability

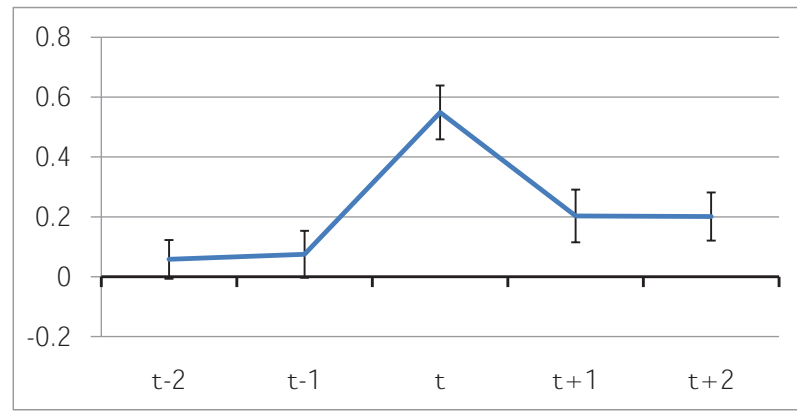

(b) Ln Deductions

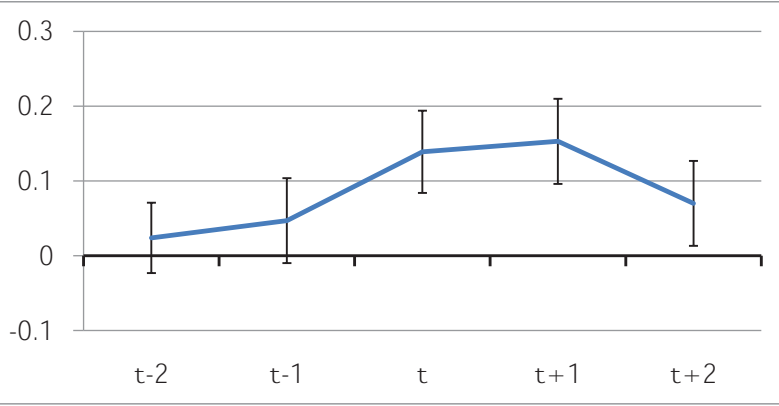

(d) Effective Tax Rate

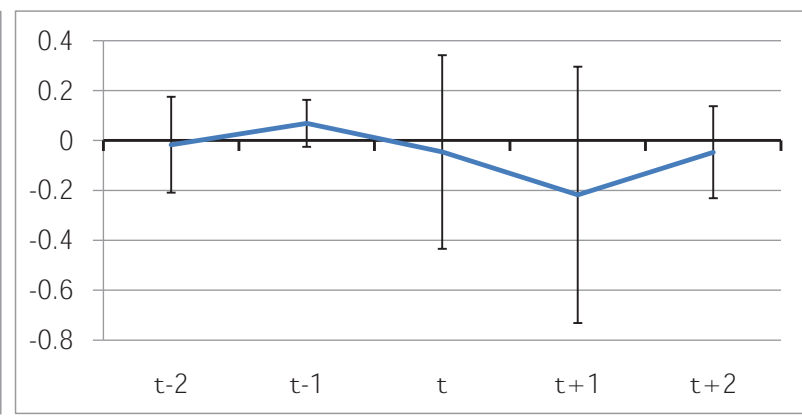

Notes: Figures plot point estimates from regressing audit dummy in year $t-h$, where $h=(-2,-1,0,1,2)$, on (a) income, (b) deductions, (c) profit tax liability, and (d) effective tax rate. Vertical lines denote the 95\% confidence intervals. Each sub-figure represents one regression. All regressions include fixed effects for firms, industries, legal forms, regions, and years; and control for log number of employees, and firm age in years. Standard errors are clustered by firm.

\section{Conclusions}

This paper studies the behavioral responses of Armenian firms to incentives implicit in the tax system. The specific attention is on the VAT registration threshold which is unusually high in Armenia, and two administrative thresholds that relax the tax compliance costs for SMEs. Our evidence suggests that firms most strongly respond to the administrative notch where locally set simplified accounting rules can be used instead of having to comply with the IFRS. We find some, but much weaker, response to the notch where the frequency to file and pay taxes decreases from monthly to quarterly for smaller firms. Unlike the existing evidence from developed countries, we do not find a strong response to the large VAT threshold. This battery of evidence suggests that in a developing country 
with a weak enforcement environment tax administration may matter more for firms' decisions than taxes.

In such an environment with potentially high rates of tax evasion, however, it is crucial to understand the mechanisms behind the response of firms. We show that the administrative notch distorts the incentives for SMEs to grow beyond the notch, since it creates discontinuously higher tax compliance costs for them. However, the evidence from audited tax returns suggests that the response is almost entirely driven by income underreporting (tax evasion) rather than real production response. This empirical result is not entirely consistent with traditional tax deterrence models where the probability to be caught along with penalties for evasion, marginal tax rates and risk-aversion predict the level of tax evasion. Such a puzzle occurs because in Armenia the audit rates are very high - about every fifth firm per year - while the other three parameters are probably somewhat standard. A potential explanation is that audits are not effective, or in other words susceptible to corruption.

These findings have direct policy implications for designing an efficient and equitable tax system. First, it seems that the VAT registration threshold in Armenia is set sufficiently high so that the compliance costs of firms of this size, on average, do not outweigh their benefits from registering as VAT payers. Yet, it is still an open question whether it is actually set too high. Second, regarding the administrative threshold, the evidence demonstrates that SMEs experience a significant benefit from rules that relax their compliance costs. This means that cleverly designed tax administration rules may have a significant impact on bolstering the SME sector. However, it is not ex-ante clear whether such policies that grant SMEs preferential treatments are welfare improving, since a significant amount of tax revenue is lost due to evasion. Therefore, the third policy implication is that such incentive mechanisms should be accompanied by optimized audit strategies which should target firms (and sectors) which have higher incentives (and opportunities) to underreport income. Finally, our results - that firms are much more responsive to administrative than tax regulations and that their response is almost entirely driven by 
tax evasion - suggests that significant reforms have to be implemented to improve the tax administration. 


\section{References}

Alm, J. (2012). Measuring, explaining, and controlling tax evasion: Lessons from theory, experiments, and field studies. International Tax and Public Finance 19(1), 54-77.

Almunia, M. and D. Lopez-Rodriguez (2014). Heterogeneous responses to effective tax enforcement: Evidence from Spanish firms. Banco de Espana, Working Paper 1419.

Armstrong, C. S., M. E. Barth, A. D. Jagolinzer, and E. J. Riedl (2010). Market reaction to the adoption of IFRS in Europe. The Accounting Review 85(2), 607-636.

Artavanis, N. T., A. Morse, and M. Tsoutsoura (2016). Measuring income tax evasion using bank credit: Evidence from Greece. Quarterly Journal of Economics forthcoming.

Bachas, P. and M. Soto (2015). Not(ch) your average tax system: Corporate taxation under weak enforcement. Mimeo, University of Berkeley.

Ball, R. (2006). International financial reporting standards: Pros and cons for investors. Accounting and Business Research 36(1), 5-27.

Bastani, S. and H. Selin (2014). Bunching and non-bunching at kink points of the Swedish tax schedule. Journal of Public Economics 109, 36-49.

Besley, T. and T. Persson (2014). Why do developing countries tax so little? The Journal of Economic Perspectives 28(4), 99-120.

Besley, T. J. and T. Persson (2013). Taxation and development. In A. J. Auerbach, R. Chetty, M. Feldstein, and E. Saez (Eds.), Handbook of public economics Vol. 5. Elsevier.

Best, M. C., A. Brockmeyer, H. J. Kleven, J. Spinnewijn, and M. Waseem (2015). Production vs revenue efficiency with limited tax capacity: Theory and evidence from Pakistan. Journal of Political Economy 123(6), 1311-1355. 
Boonzaaier, W., J. Harju, T. Matikka, and J. Pirttilä (2016). How do small firms respond to tax schedule discontinuities? Evidence from South African tax registers. Mimeo.

Brashares, E., M. Knittel, G. Silverstein, and A. Yuskavage (2014). Calculating the optimal small business exemption threshold for a U.S. VAT. National Tax Journal 67(2), $283-320$.

Carrillo, P., D. Pomeranz, and M. Singhal (2016). Dodging the taxman: Firm misreporting and limits to tax enforcement. American Economic Journal: Applied Economics forthcoming.

Carrillo, P. E., M. S. Emran, and R. Anita (2012). Do cheaters bunch together? Profit taxes, withholding rates and tax evasion. George Washington University 2011-3.

Casaburi, L. and U. Troiano (2015). Ghost-house busters: The electoral response to a large anti tax evasion program. Quarterly Journal of Economics (forthcoming).

Chetty, R., J. N. Friedman, T. Olsen, and L. Pistaferri (2011). Adjustment costs, firm responses, and micro vs. macro labor supply elasticities: Evidence from Danish tax records. Quarterly Journal of Economics 126(2), 749-804.

Coolidge, J. (2012). Findings of tax compliance cost surveys in developing countries. eJournal of Tax Research 10(2), 250-287.

Daske, H. (2006). Economic benefits of adopting IFRS or US-GAAP - have the expected cost of equity capital really decreased? Journal of Business Finance and Accounting 33(3-4), 329-373.

Daske, H., L. Hail, C. Leuz, and R. Verdi (2013). Adopting a label: Heterogeneity in the economic consequences around IAS/IFRS adoptions. Journal of Accounting Research $51(3), 495-547$. 
DeBacker, J., B. T. Heim, A. Tran, and A. Yuskavage (2015). Legal enforcement and corporate behavior: An analysis of tax aggressiveness after an audit. Journal of Law and Economics 58(2), 291-324.

DeGeorge, E. T., C. B. Ferguson, and N. A. Spear (2012). How much does IFRS cost? IFRS adoption and audit fees. The Accounting Review 88(2), 429-462.

Devereux, M. P., L. Liu, , and S. Loretz (2014). The elasticity of corporate taxable income: New evidence from UK tax records. American Economic Journal: Economic Policy 6(2), 19-53.

Dharmapala, D., J. Slemrod, and J. D. Wilson (2011). Tax policy and the missing middle: Optimal tax remittance with firm-level administrative costs. Journal of Public Economics 95(9-10), 1036-1047.

Diamond, P. A. and J. A. Mirrlees (1971). Optimal taxation and public production I: Production efficiency. The American Economic Review 61(1), 8-27.

Eichfelder, S. and F. Vaillancourt (2014). Tax compliance costs: A review of cost burdens and cost structures. ARQUS Discussion Paper No. 178.

Engelschalk, M. and J. Loeprick (2016). The taxation of micro and small businesses in transition economies: Country experience of the introduction of special tax regimes. Journal of Tax Administration 2(1), 145-197.

Fuest, C. and G. R. Zodrow (2013). Critical Issues in Taxation and Development. Cambridge, MA: MIT Press.

Gebresilasse, M. M. and S. Sow (2016). Firm response to VAT policy: Evidence from Ethiopia. Columbia University, mimeo.

Government of the Republic of Armenia (2009). Summary report on implementation of RA government anti-crisis action plan. Yerevan, Armenia. 
Harju, J., T. Matikka, and T. Rauhanen (2015). The effect of VAT threshold on the behavior of small businesses. CESifo area conference on public sector economics.

Hsieh, C.-T. and B. A. Olken (2014). The missing "missing middle". The Journal of Economic Perspectives 28(3), 89-108.

International Finance Corporation (2011). The costs of tax compliance in Armenia. Yerevan, Armenia.

Kanbur, R. and M. Keen (2014). Thresholds, informality, and partitions of compliance. International Tax and Public Finance 21(4), 536-559.

Keen, M. and B. Lockwood (2006). Is the VAT a money machine? National Tax Journal 59(4), 905-928.

Keen, M. and B. Lockwood (2010). The value added tax: Its causes and consequences. Journal of Development Economics 92(2), 138-151.

Keen, M. and J. Mintz (2004). The optimal threshold for a value-added tax. Journal of Public Economics 88(3), 559-576.

Kleven, H. J. (2016). Bunching. Annual Review of Economics 8.

Kleven, H. J., M. B. Knudsen, C. T. Kreiner, S. Pedersen, and E. Saez (2011). Unwilling or unable to cheat? Evidence from a tax audit experiment in Denmark. Econometrica $79(3), 651-692$.

Kleven, H. J. and M. Waseem (2013). Using notches to uncover optimization frictions and structural elasticities: Theory and evidence from Pakistan. Quarterly Journal of Economics 128(2), 669-723.

Le Maire, D. and B. Schjerning (2013). Tax bunching, income shifting and selfemployment. Journal of Public Economics 10\%, 1-18. 
Liu, L. and B. Lockwood (2015). VAT notches. Oxford University Centre for Business Taxation 15-06.

Marion, J. and E. Muehlegger (2008). Measuring illegal activity and the effects of regulatory innovation: Tax evasion and the dyeing of untaxed diesel. Journal of Political Economy 116(4), 633-666.

Onji, K. (2009). The response of firms to eligibility thresholds: Evidence from the Japanese value-added tax. Journal of Public Economics 93(5), 766-775.

Pomeranz, D. (2015). No taxation without information: Deterrence and self-enforcement in the value added tax. American Economic Review 105(8), 2539-2569.

Republic of Armenia (2014a). The law of RA on accounting. http://www.parliament. am/law_docs/310103H0515eng.pdf.

Republic of Armenia (2014b). The law of RA on value added tax. http://www . parliament.am/legislation.php?sel=show\&ID=1607\&lang=eng.

Saez, E. (2010). Do taxpayers bunch at kink points? American Economic Journal: Economic Policy 2(3), 180-212.

Saez, E., J. Slemrod, and S. H. Giertz (2012). The Elasticity of Taxable Income with Respect to Marginal Tax Rates: A Critical Review. Journal of Economic Literature 50(1), $3-50$.

Slemrod, J. (2007). Cheating ourselves: The economics of tax evasion. Journal of Economic Perspectives 21(1), 25-48.

Slemrod, J. (2013). Buenas notches: lines and notches in tax system design. eJournal of Tax Research 11(3), 259-283.

Slemrod, J. and C. Gillitzer (2013). Tax Systems. Cambridge, MA: MIT Press. 
Slemrod, J. and S. Yitzhaki. (2002). Tax avoidance, evasion, and administration. Handbook of public economics 3 .

USAID (2014). Tax perceptions in Armenia. Yerevan, Armenia.

Waseem, M. (2016). Taxes, informality and income shifting: Evidence from a recent Pakistani tax reform. University of Manchester, mimeo. 


\section{Appendix}

Figure A1: Size-Distribution of FIRMs, 2007-13

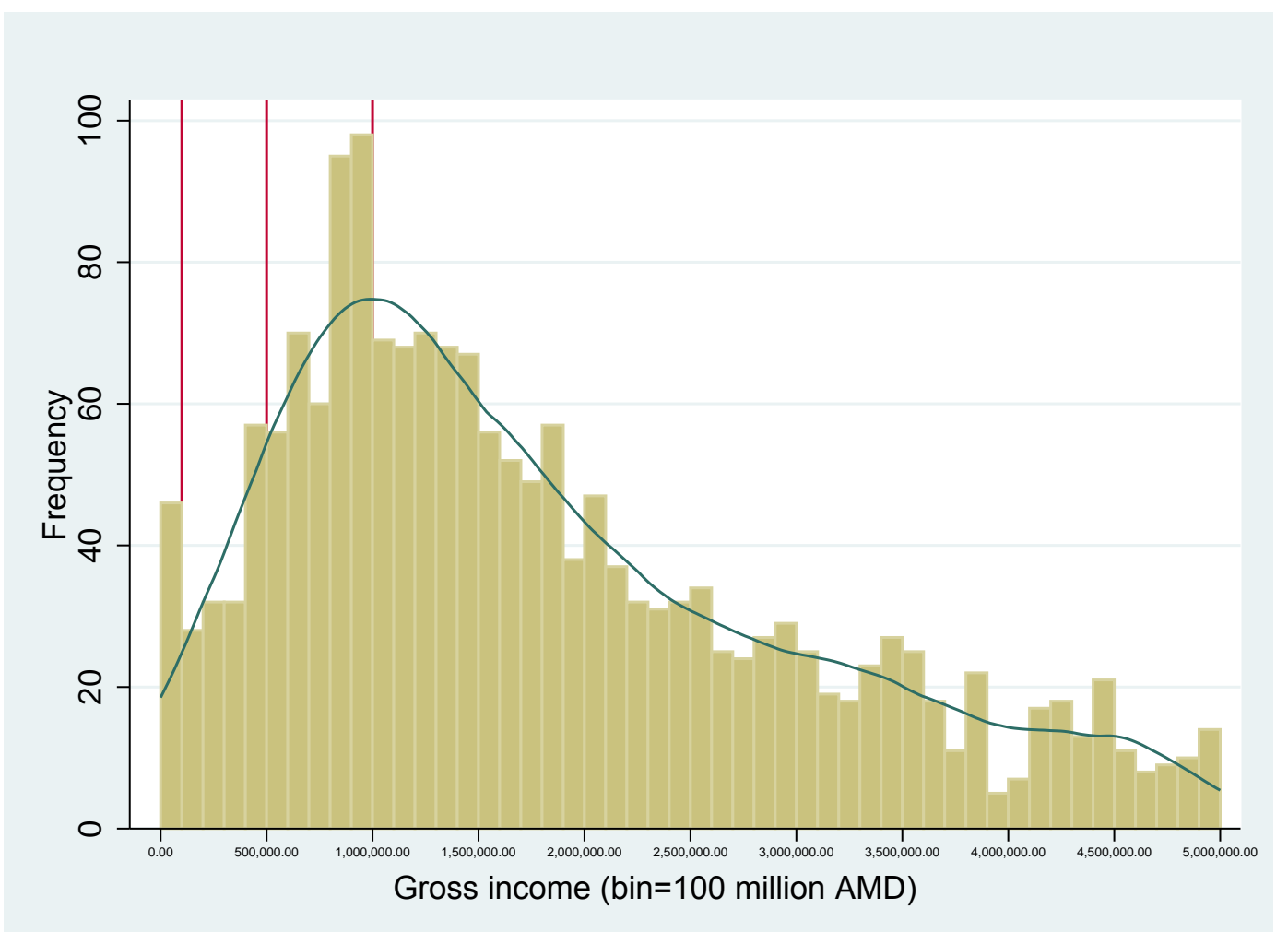

Notes: Figure shows the size-distribution of larger firms in bins of 100 million AMD in the years 2007 to 2013. Data is trimmed below 100 (where most - about $72 \%$ - of observations are) and above 5,000 (where only about $1 \%$ of observations are) million AMD of gross income. The first, second and third vertical lines denote three thresholds where, respectively, rules of tax administration change, firms qualify to enter the large taxpayer unit, and firms are obliged to publish financial statements (for more details, see, Figure 2). 
Figure A2: Distribution of input costs to turnover By SECTOR

(a) Construction

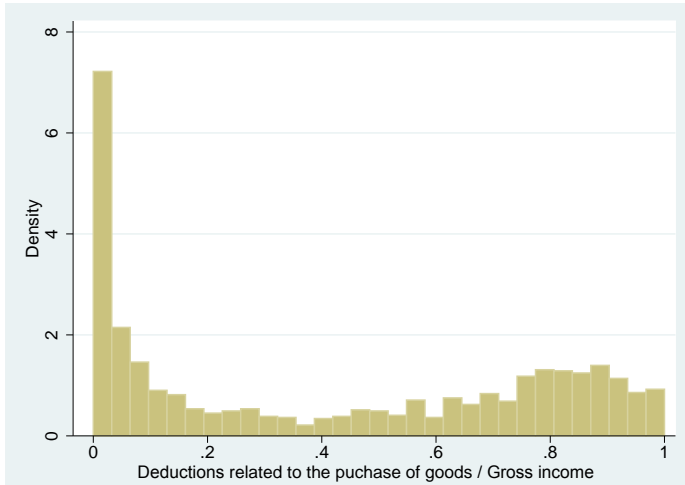

(c) Service

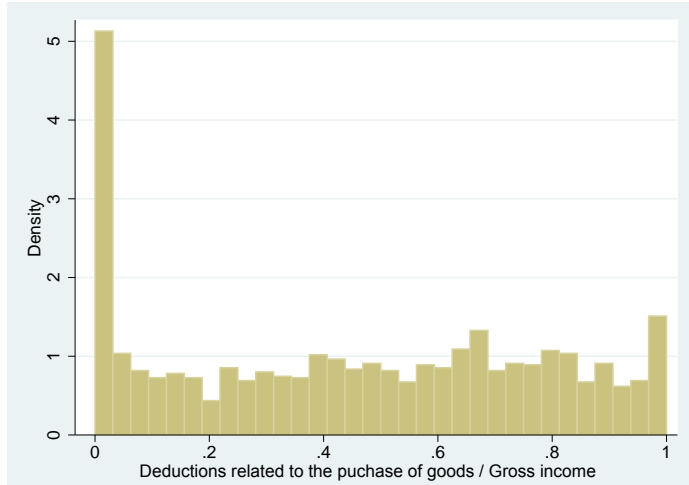

(e) Other sectors

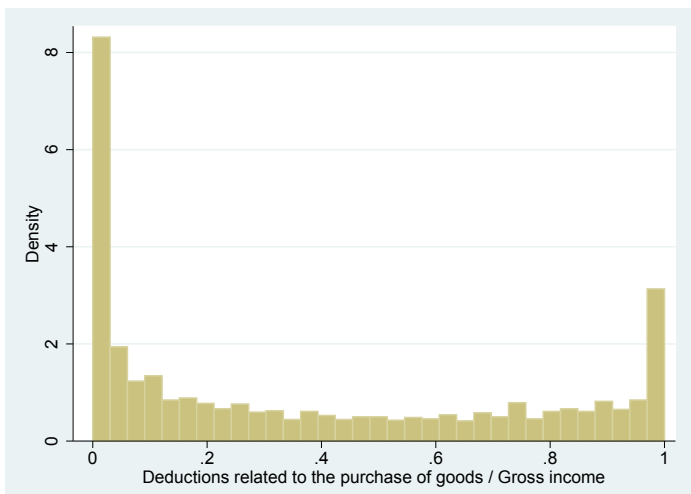

(b) Manufacturing

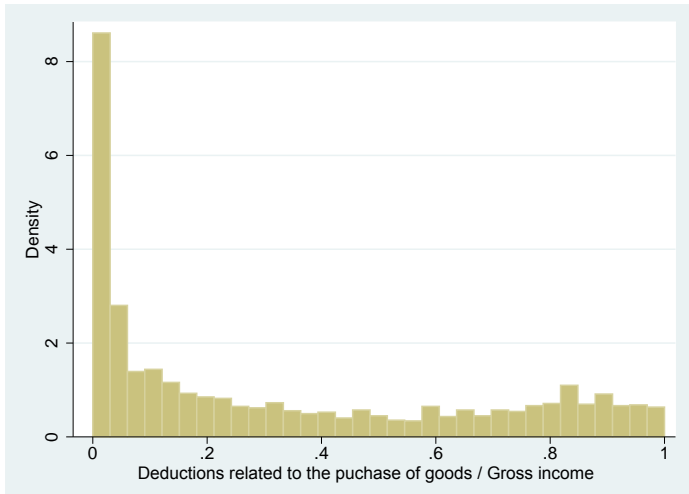

(d) Trade

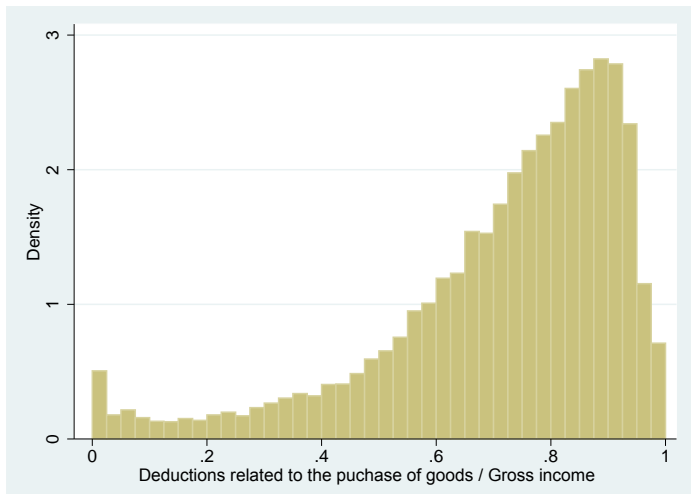

(f) All firms

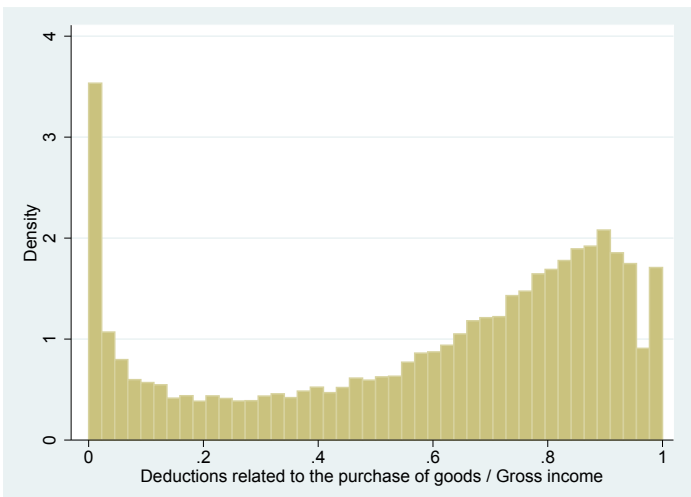

Notes: Figures plot histograms of firms per industry (and in (f) for all firms) according to the ratio of deductions directly related to the purchase of goods in gross income. 
Figure A3: Sensitivity of BUnChing estimates

(a) Choice of exCluded Region

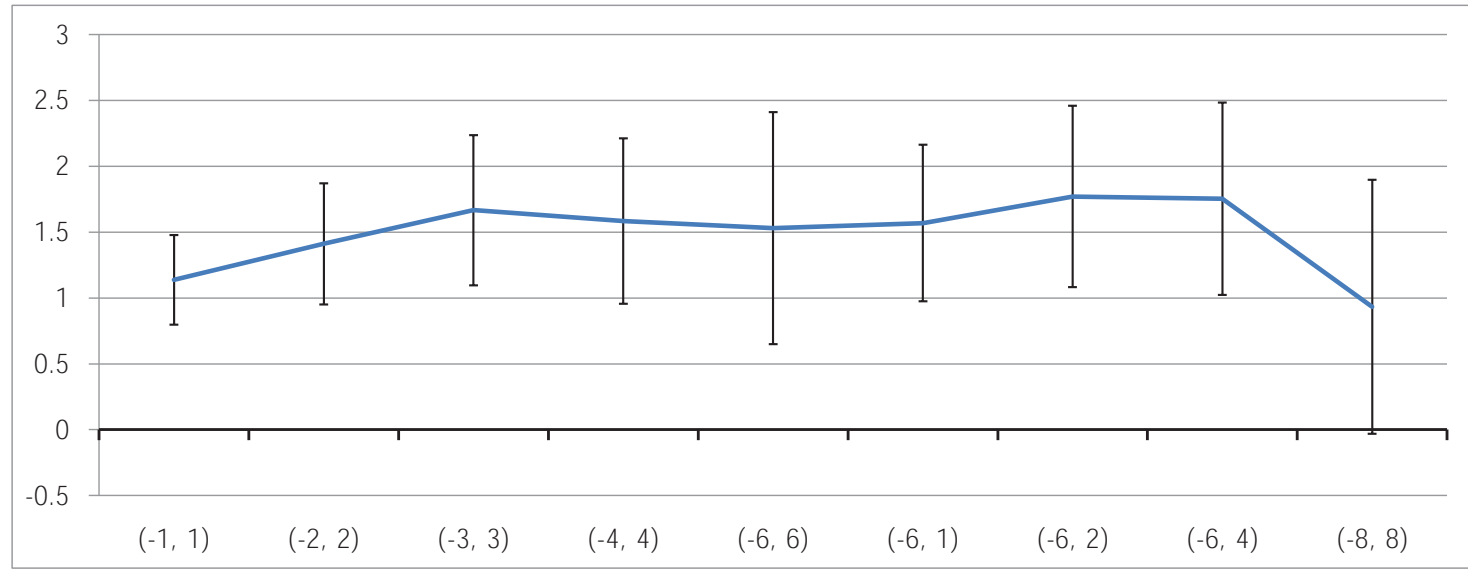

(b) Choice of the Degree of polynomial

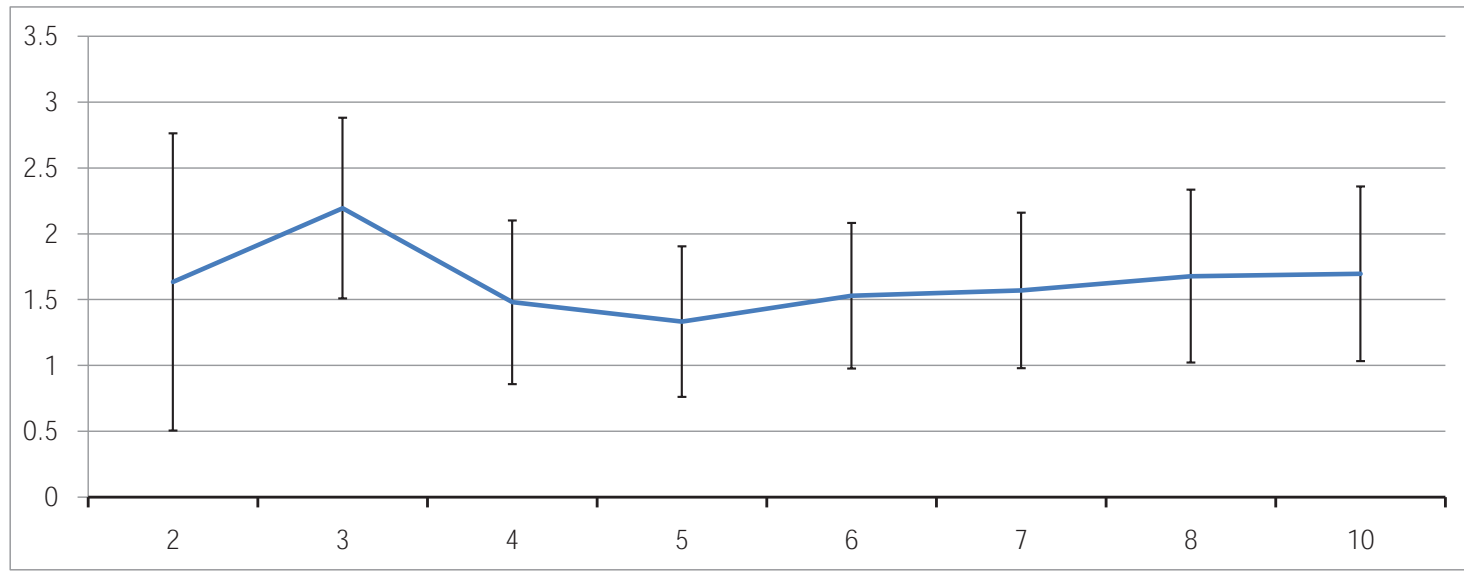

Notes: Figures present sensitivity tests of the bunching estimate of Figure 6a: (a) to the selection of the excluded region (x-axis denotes the excluded bins of 1,000 thousand AMD); and (b) to the choice of the polynomial in estimating the counterfactual distribution ( $\mathrm{x}$-axis denotes the degree of the polynomial). Vertical lines denote the $95 \%$ confidence intervals.

Figure A4: Response to ACCOUnting RUles V.S. FREQUENCY Of FILING

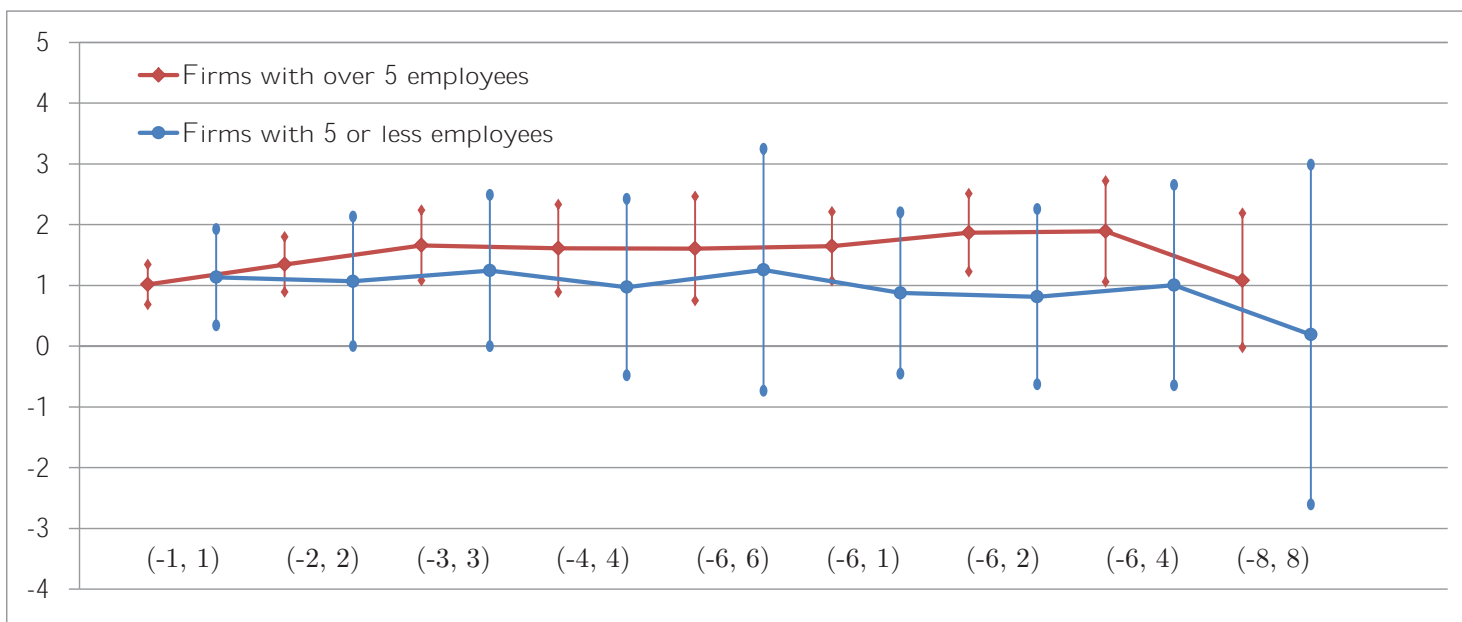

Notes: Figures presents the bunching estimates separately for small and large firms across the choice of the excluded area (x-axis denotes the excluded bins of 1,000 thousand AMD). Firms with 5 or less employees qualify to use the simplified accounting rules independent of their income, therefore any response should be driven by the frequency of filing rules. 
Table A1: VAT REgistration thresholds in USD AROUnd THE WORLD IN 2013

\begin{tabular}{|c|c|c|c|c|c|c|c|c|}
\hline No & Country & Threshold & No & Country & Threshold & No & Country & Threshold \\
\hline 1 & Singapore & 799,169 & 36 & Morocco & 59,485 & 71 & India & 8,533 \\
\hline 2 & Jersey & 468,999 & 37 & Thailand & 58,582 & 72 & Norway & 8,511 \\
\hline 3 & Seychelles & 414,652 & 38 & Kenya & 58,057 & 73 & Belgium & 7,409 \\
\hline 4 & Kazakhstan & 346,200 & 39 & Indonesia & 57,355 & 74 & El Salvador & 5,714 \\
\hline 5 & Azerbaijan & 152,956 & 40 & Trinidad \& Tobago & 55,878 & 75 & Algeria & 1,260 \\
\hline 6 & Zambia & 148,261 & 41 & Czech Republic & 51,097 & 76 & Belarus & 0 \\
\hline 7 & Armenia & 142,447 & 42 & New Zealand & 49,204 & 77 & Bolivia & 0 \\
\hline 8 & Isle of Man & 123,503 & 43 & Pakistan & 49,199 & 78 & Bonaire, S. Eust. \& Saba & 0 \\
\hline 9 & United Kingdom & 123,503 & 44 & Moldova & 47,669 & 79 & Chile & 0 \\
\hline 10 & Gabon & 121,448 & 45 & Poland & 47,459 & 80 & Colombia & 0 \\
\hline 11 & Papua New Guinea & 111,383 & 46 & Albania & 47,318 & 81 & Costa Rica & 0 \\
\hline 12 & Argentina & 109,903 & 47 & Malta & 46,471 & 82 & Dominican Republic & 0 \\
\hline 13 & France & 108,211 & 48 & Philippines & 45,222 & 83 & Ecuador & 0 \\
\hline 14 & Switzerland & 107,886 & 49 & Macedonia & 43,108 & 84 & Greece & 0 \\
\hline 15 & South Africa & 103,573 & 50 & Croatia & 40,316 & 85 & Guatemala & 0 \\
\hline 16 & Japan & 102,464 & 51 & Austria & 39,832 & 86 & Honduras & 0 \\
\hline 17 & Ireland & 99,581 & 52 & China & 38,736 & 87 & Iceland & 0 \\
\hline 18 & Lebanon & 99,502 & 53 & Ukraine & 37,533 & 88 & Italy & 0 \\
\hline 19 & Serbia & 93,942 & 54 & Panama & 36,000 & 89 & Korea & 0 \\
\hline 20 & Madagascar & 90,624 & 55 & Bulgaria & 33,931 & 90 & Mexico & 0 \\
\hline 21 & Romania & 86,303 & 56 & Luxembourg & 33,194 & 91 & Netherlands & 0 \\
\hline 22 & Barbados & 80,000 & 57 & Malaysia & 31,737 & 92 & Nicaragua & 0 \\
\hline 23 & Bangladesh & 76,821 & 58 & Rwanda & 30,929 & 93 & Nigeria & 0 \\
\hline 24 & Australia & 72,405 & 59 & Canada & 29,132 & 94 & Paraguay & 0 \\
\hline 25 & Jordan & 70,423 & 60 & Tanzania & 24,993 & 95 & Peru & 0 \\
\hline 26 & Slovenia & 66,387 & 61 & Montenegro & 23,899 & 96 & Portugal & 0 \\
\hline 27 & Latvia & 66,114 & 62 & Germany & 23,235 & 97 & Puerto Rico & 0 \\
\hline 28 & Slovak Republic & 66,108 & 63 & Hungary & 22,352 & 98 & Russian Federation & 0 \\
\hline 29 & Mauritius & 65,144 & 64 & Israel & 21,293 & 99 & Spain & 0 \\
\hline 30 & Tunisia & 61,551 & 65 & Estonia & 21,244 & 100 & Sweden & 0 \\
\hline 31 & Ghana & 61,411 & 66 & Namibia & 20,715 & 101 & Taiwan & 0 \\
\hline 32 & Georgia & 60,120 & 67 & Cyprus & 20,713 & 102 & Turkey & 0 \\
\hline 33 & Zimbabwe & 60,000 & 68 & Uganda & 19,328 & 103 & Uruguay & 0 \\
\hline 34 & Lithuania & 59,592 & 69 & Finland & 11,286 & 104 & Venezuela & 0 \\
\hline 35 & Botswana & 59,532 & 70 & Denmark & 8,903 & 105 & Vietnam & 0 \\
\hline
\end{tabular}

Notes: Source of data is Asatryan and Todtenhaupt (2016). Thresholds apply to goods (when different thresholds apply) and are typically set in local currency. Annual average nominal exchange rates are used for conversion to USD. 
Table A2: Probit estimates: Determinants of bunchers

\begin{tabular}{|c|c|c|c|c|c|c|c|c|c|c|c|c|}
\hline \multirow{2}{*}{$\begin{array}{l}\text { VARIABLES } \\
\text { Ln Employees }\end{array}$} & \multicolumn{6}{|c|}{ Bunching below $5 \%$ of threshold } & \multicolumn{6}{|c|}{ Bunching below $10 \%$ threshold } \\
\hline & $\begin{array}{c}-0.028 \\
(0.018)\end{array}$ & $\begin{array}{c}-0.022 \\
(0.021)\end{array}$ & $\begin{array}{c}-0.020 \\
(0.021)\end{array}$ & $\begin{array}{l}-0.009 \\
(0.029)\end{array}$ & $\begin{array}{c}0.029 \\
(0.033)\end{array}$ & $\begin{array}{c}-0.022 \\
(0.022)\end{array}$ & $\begin{array}{c}-0.025^{*} \\
(0.014)\end{array}$ & $\begin{array}{c}-0.019 \\
(0.017)\end{array}$ & -0.018 & & & $\begin{array}{l}-0.018 \\
(0.017)\end{array}$ \\
\hline Ln Turnover & $\begin{array}{c}0.115^{* * * *} \\
(0.009)\end{array}$ & $\begin{array}{c}0.090 * * * \\
(0.010)\end{array}$ & $\begin{array}{c}0.095^{* * *} * \\
(0.011)\end{array}$ & $\begin{array}{c}0.097^{* * *} \\
(0.015)\end{array}$ & $\begin{array}{c}0.053^{* * *} * \\
(0.017)\end{array}$ & $\begin{array}{c}0.093^{* * *} * \\
(0.010)\end{array}$ & $\begin{array}{c}0.123 * * * \\
(0.007)\end{array}$ & $\begin{array}{c}0.091^{* * * *} \\
(0.009)\end{array}$ & $\begin{array}{c}0.094^{* * *} \\
(0.009)\end{array}$ & $\begin{array}{c}0.100^{* * *} \\
(0.013)\end{array}$ & $\begin{array}{c}0.073^{* * *} * \\
(0.015)\end{array}$ & $\begin{array}{c}0.096 * * * \\
(0.009)\end{array}$ \\
\hline Firm age & $\begin{array}{c}0.002 \\
(0.004)\end{array}$ & $\begin{array}{c}0.000 \\
(0.004)\end{array}$ & $\begin{array}{c}0.001 \\
(0.004)\end{array}$ & $\begin{array}{c}0.002 \\
(0.005)\end{array}$ & $\begin{array}{l}-0.003 \\
(0.006)\end{array}$ & $\begin{array}{c}0.000 \\
(0.004)\end{array}$ & $\begin{array}{c}0.001 \\
(0.003)\end{array}$ & $\begin{array}{c}0.001 \\
(0.003)\end{array}$ & $\begin{array}{c}0.001 \\
(0.003)\end{array}$ & $\begin{array}{c}0.002 \\
(0.004)\end{array}$ & $\begin{array}{l}-0.001 \\
(0.005)\end{array}$ & $\begin{array}{c}0.001 \\
(0.003)\end{array}$ \\
\hline Profit tax/Turnover & $\begin{array}{c}0.442 \\
(0.838)\end{array}$ & $\begin{array}{l}1.246^{*} \\
(0.662)\end{array}$ & $\begin{array}{c}1.384^{* *} \\
(0.648)\end{array}$ & $\begin{array}{c}1.046 \\
(0.965)\end{array}$ & $\begin{array}{c}0.009 \\
(1.262)\end{array}$ & $\begin{array}{c}1.316^{* *} \\
(0.663)\end{array}$ & $\begin{array}{c}0.738 \\
(0.612)\end{array}$ & $\begin{array}{l}1.268^{* *} \\
(0.503)\end{array}$ & $\begin{array}{c}1.363^{* * *} * \\
(0.501)\end{array}$ & $\begin{array}{l}1.175^{*} \\
(0.692)\end{array}$ & $\begin{array}{c}0.716 \\
(0.800)\end{array}$ & $\begin{array}{c}1.344^{* * *} \\
(0.497)\end{array}$ \\
\hline Deductions/Turnover & $\begin{array}{c}0.166 \\
(0.131)\end{array}$ & $\begin{array}{c}0.075 \\
(0.075)\end{array}$ & $\begin{array}{c}0.069 \\
(0.070)\end{array}$ & $\begin{array}{c}0.163 \\
(0.131)\end{array}$ & $\begin{array}{c}0.191 \\
(0.173)\end{array}$ & $\begin{array}{c}0.079 \\
(0.074)\end{array}$ & $\begin{array}{c}0.154^{*} \\
(0.090)\end{array}$ & $\begin{array}{c}0.053 \\
(0.036)\end{array}$ & $\begin{array}{c}0.050 \\
(0.035)\end{array}$ & $\begin{array}{c}0.090 \\
(0.056)\end{array}$ & $\begin{array}{c}0.104 \\
(0.077)\end{array}$ & $\begin{array}{c}0.054 \\
(0.034)\end{array}$ \\
\hline Buncher dummy (t-1) & & $\begin{array}{c}0.581^{* * *} * \\
(0.104)\end{array}$ & $\begin{array}{c}0.580^{* * *} * \\
(0.104)\end{array}$ & $\begin{array}{c}0.726^{* * *} \\
(0.134)\end{array}$ & $\begin{array}{c}0.630^{* * *} \\
(0.157)\end{array}$ & $\begin{array}{c}0.349^{* *} \\
(0.151)\end{array}$ & & $\begin{array}{c}0.687^{* * *} \\
(0.060)\end{array}$ & $\begin{array}{c}0.686^{* * * *} \\
(0.060)\end{array}$ & $\begin{array}{c}0.790^{* * *} \\
(0.077)\end{array}$ & $\begin{array}{c}0.719^{* * * *} \\
(0.093)\end{array}$ & $\begin{array}{c}0.448^{* * *} * \\
(0.078)\end{array}$ \\
\hline Dummy positive evasion & & & $\begin{array}{l}-0.090 \\
(0.059)\end{array}$ & & & & & & $\begin{array}{l}-0.063 \\
(0.048)\end{array}$ & & & \\
\hline Dummy announced audit & $\mathrm{t}(\mathrm{t}-1)$ & & & $\begin{array}{c}-0.153^{* *} \\
(0.076)\end{array}$ & & & & & & $\begin{array}{c}-0.244^{* * *} \\
(0.060)\end{array}$ & & \\
\hline $\begin{array}{l}\text { Dummy audit }(\mathrm{t}) \\
\text { Industry }(\text { base }=\text { Trade) }\end{array}$ & & & & & $\begin{array}{c}0.009 \\
(0.072)\end{array}$ & & & & & & $\begin{array}{c}0.011 \\
(0.059)\end{array}$ & \\
\hline Const & $\begin{array}{c}0.120^{* *} \\
(0.056)\end{array}$ & $\begin{array}{l}0.111^{*} \\
(0.063)\end{array}$ & $\begin{array}{c}0.122^{* *} \\
(0.062)\end{array}$ & $\begin{array}{c}0.101 \\
(0.086)\end{array}$ & $\begin{array}{c}0.081 \\
(0.105)\end{array}$ & $\begin{array}{l}0.111^{*} \\
(0.064)\end{array}$ & $\begin{array}{l}0.087^{*} \\
(0.045)\end{array}$ & $\begin{array}{c}0.044 \\
(0.050)\end{array}$ & $\begin{array}{c}0.051 \\
(0.050)\end{array}$ & $\begin{array}{c}0.058 \\
(0.066)\end{array}$ & $\begin{array}{c}0.061 \\
(0.080)\end{array}$ & $\begin{array}{c}0.038 \\
(0.051)\end{array}$ \\
\hline Finance & $\begin{array}{c}-0.443^{* * *} \\
(0.155)\end{array}$ & $\begin{array}{c}-0.505^{* * *} \\
(0.170)\end{array}$ & $\begin{array}{c}-0.517^{* * *} \\
(0.171)\end{array}$ & $\begin{array}{c}-0.292 \\
(0.180)\end{array}$ & $\begin{array}{l}-0.355 \\
(0.254)\end{array}$ & $\begin{array}{c}-0.513^{* * *} \\
(0.172)\end{array}$ & $\begin{array}{c}-0.528^{* * *} * \\
(0.131)\end{array}$ & $\begin{array}{c}-0.575^{* * *} \\
(0.145)\end{array}$ & $\begin{array}{c}-0.584 * * * \\
(0.146)\end{array}$ & $\begin{array}{c}-0.487^{* * *} \\
(0.178)\end{array}$ & $\begin{array}{c}-0.557^{* *} \\
(0.272)\end{array}$ & $\begin{array}{c}-0.583^{* * *} \\
(0.150)\end{array}$ \\
\hline IT & $\begin{array}{c}0.195^{* *} \\
(0.083)\end{array}$ & $\begin{array}{c}0.164^{*} \\
(0.093)\end{array}$ & $\begin{array}{l}0.156^{*} \\
(0.093)\end{array}$ & $\begin{array}{c}0.195 \\
(0.119)\end{array}$ & $\begin{array}{l}-0.002 \\
(0.158)\end{array}$ & $\begin{array}{l}0.162^{*} \\
(0.094)\end{array}$ & $\begin{array}{c}0.098 \\
(0.075)\end{array}$ & $\begin{array}{c}0.046 \\
(0.084)\end{array}$ & $\begin{array}{c}0.041 \\
(0.084)\end{array}$ & $\begin{array}{c}0.089 \\
(0.104)\end{array}$ & $\begin{array}{c}0.030 \\
(0.127)\end{array}$ & $\begin{array}{c}0.047 \\
(0.084)\end{array}$ \\
\hline Manufacturing & $\begin{array}{c}0.155^{* *} \\
(0.063)\end{array}$ & $\begin{array}{c}0.147^{* *} \\
(0.070)\end{array}$ & $\begin{array}{c}0.148^{* *} \\
(0.070)\end{array}$ & $\begin{array}{c}0.183^{* *} \\
(0.090)\end{array}$ & $\begin{array}{c}0.215^{* *} \\
(0.102)\end{array}$ & $\begin{array}{c}0.149^{* *} \\
(0.071)\end{array}$ & $\begin{array}{c}0.102^{* *} \\
(0.051)\end{array}$ & $\begin{array}{c}0.061 \\
(0.056)\end{array}$ & $\begin{array}{c}0.061 \\
(0.056)\end{array}$ & $\begin{array}{c}0.086 \\
(0.070)\end{array}$ & $\begin{array}{l}0.135^{*} \\
(0.080)\end{array}$ & $\begin{array}{c}0.060 \\
(0.057)\end{array}$ \\
\hline Mining & $\begin{array}{c}0.000 \\
(0.000)\end{array}$ & $\begin{array}{c}0.000 \\
(0.000)\end{array}$ & $\begin{array}{c}0.000 \\
(0.000)\end{array}$ & $\begin{array}{c}0.000 \\
(0.000)\end{array}$ & $\begin{array}{c}0.000 \\
(0.000)\end{array}$ & $\begin{array}{c}0.000 \\
(0.000)\end{array}$ & $\begin{array}{c}-0.392^{* * *} \\
(0.133)\end{array}$ & $\begin{array}{c}-0.687^{* * *} \\
(0.199)\end{array}$ & $\begin{array}{c}-0.686 * * * \\
(0.199)\end{array}$ & $\begin{array}{c}-0.834^{* *} \\
(0.332)\end{array}$ & $\begin{array}{c}-0.679^{* *} \\
(0.346)\end{array}$ & $\begin{array}{c}-0.700^{* * *} \\
(0.200)\end{array}$ \\
\hline Missing & $\begin{array}{l}-0.048 \\
(0.074)\end{array}$ & $\begin{array}{l}-0.004 \\
(0.107)\end{array}$ & $\begin{array}{l}-0.007 \\
(0.107)\end{array}$ & & & $\begin{array}{l}-0.000 \\
(0.109)\end{array}$ & $\begin{array}{l}-0.068 \\
(0.056)\end{array}$ & $\begin{array}{l}-0.031 \\
(0.081)\end{array}$ & $\begin{array}{l}-0.033 \\
(0.081)\end{array}$ & & & $\begin{array}{l}-0.023 \\
(0.082)\end{array}$ \\
\hline Public administration & $\begin{array}{c}0.144 \\
(0.404)\end{array}$ & $\begin{array}{l}-0.004 \\
(0.371)\end{array}$ & $\begin{array}{l}-0.009 \\
(0.370)\end{array}$ & $\begin{array}{c}0.194 \\
(0.423)\end{array}$ & $\begin{array}{c}0.361 \\
(0.457)\end{array}$ & $\begin{array}{l}-0.016 \\
(0.376)\end{array}$ & $\begin{array}{l}-0.008 \\
(0.317)\end{array}$ & $\begin{array}{l}-0.370 \\
(0.373)\end{array}$ & $\begin{array}{l}-0.374 \\
(0.373)\end{array}$ & $\begin{array}{l}-0.194 \\
(0.425)\end{array}$ & $\begin{array}{c}0.020 \\
(0.459)\end{array}$ & $\begin{array}{l}-0.384 \\
(0.375)\end{array}$ \\
\hline Servi & $\begin{array}{c}0.057 \\
(0.060)\end{array}$ & $\begin{array}{c}0.015 \\
(0.066)\end{array}$ & $\begin{array}{c}0.010 \\
(0.067)\end{array}$ & $\begin{array}{c}0.049 \\
(0.082)\end{array}$ & $\begin{array}{c}0.046 \\
(0.100)\end{array}$ & $\begin{array}{c}0.018 \\
(0.067)\end{array}$ & $\begin{array}{c}0.002 \\
(0.049)\end{array}$ & $\begin{array}{c}-0.048 \\
(0.054)\end{array}$ & $\begin{array}{l}-0.052 \\
(0.054)\end{array}$ & $\begin{array}{l}-0.085 \\
(0.068)\end{array}$ & $\begin{array}{l}-0.025 \\
(0.080)\end{array}$ & $\begin{array}{l}-0.045 \\
(0.055)\end{array}$ \\
\hline Transpor & $\begin{array}{l}-0.020 \\
(0.104)\end{array}$ & $\begin{array}{l}-0.083 \\
(0.127)\end{array}$ & $\begin{array}{l}-0.090 \\
(0.127)\end{array}$ & $\begin{array}{l}-0.126 \\
(0.163)\end{array}$ & $\begin{array}{c}-0.055 \\
(0.184)\end{array}$ & $\begin{array}{l}-0.087 \\
(0.129)\end{array}$ & $\begin{array}{l}-0.008 \\
(0.088)\end{array}$ & $\begin{array}{l}-0.146 \\
(0.109)\end{array}$ & $\begin{array}{l}-0.150 \\
(0.109)\end{array}$ & $\begin{array}{l}-0.151 \\
(0.127)\end{array}$ & $\begin{array}{l}-0.115 \\
(0.148)\end{array}$ & $\begin{array}{l}-0.147 \\
(0.110)\end{array}$ \\
\hline $\begin{array}{l}\text { Utilities } \\
\text { Legal Inc. }(\text { base }=\text { CJSC })\end{array}$ & $\begin{array}{c}0.070 \\
(0.071)\end{array}$ & $\begin{array}{c}0.100 \\
(0.076)\end{array}$ & $\begin{array}{c}0.097 \\
(0.076)\end{array}$ & $\begin{array}{c}0.066 \\
(0.099)\end{array}$ & $\begin{array}{c}0.032 \\
(0.121)\end{array}$ & $\begin{array}{c}0.102 \\
(0.077)\end{array}$ & $\begin{array}{c}0.011 \\
(0.059)\end{array}$ & $\begin{array}{l}-0.034 \\
(0.064)\end{array}$ & $\begin{array}{l}-0.037 \\
(0.064)\end{array}$ & $\begin{array}{l}-0.083 \\
(0.086)\end{array}$ & $\begin{array}{l}-0.060 \\
(0.100)\end{array}$ & $\begin{array}{l}-0.027 \\
(0.066)\end{array}$ \\
\hline Community Enterprise & $\begin{array}{c}0.000 \\
(0.000)\end{array}$ & $\begin{array}{r}0.0 \\
(0.0\end{array}$ & $\begin{array}{c}0.000 \\
(0.000)\end{array}$ & $\begin{array}{c}0.000 \\
(0.000)\end{array}$ & $\begin{array}{c}0.000 \\
(0.000)\end{array}$ & $\begin{array}{l}0.0 \\
(0.0\end{array}$ & $\begin{array}{l}-0.112 \\
(0.267)\end{array}$ & $\begin{array}{l}-0 . \\
0 .\end{array}$ & $\begin{array}{l}-0 . \\
(0.3\end{array}$ & $\begin{array}{l}0 . \\
0 .\end{array}$ & $\begin{array}{l}0 . \\
0 .\end{array}$ & $\begin{array}{l}-0.192 \\
(0.373)\end{array}$ \\
\hline Foundation & $\begin{array}{l}0.321^{*} \\
(0.183)\end{array}$ & $\begin{array}{c}0.159 \\
(0.199)\end{array}$ & $\begin{array}{c}0.152 \\
(0.199)\end{array}$ & $\begin{array}{c}0.214 \\
(0.283)\end{array}$ & $\begin{array}{c}0.051 \\
(0.398)\end{array}$ & $\begin{array}{c}0.161 \\
(0.204)\end{array}$ & $\begin{array}{c}0.255 \\
(0.158)\end{array}$ & $\begin{array}{c}0.204 \\
(0.166)\end{array}$ & $\begin{array}{c}0.199 \\
(0.166)\end{array}$ & $\begin{array}{c}0.220 \\
(0.258)\end{array}$ & $\begin{array}{c}0.026 \\
(0.303)\end{array}$ & $\begin{array}{c}0.224 \\
(0.170)\end{array}$ \\
\hline LLC & $\begin{array}{c}0.092 \\
(0.059)\end{array}$ & $\begin{array}{c}0.042 \\
(0.065)\end{array}$ & $\begin{array}{c}0.045 \\
(0.065)\end{array}$ & $\begin{array}{l}0.155^{*} \\
(0.092)\end{array}$ & $\begin{array}{c}0.131 \\
(0.108)\end{array}$ & $\begin{array}{l}0.045 \\
(0.066)\end{array}$ & $\begin{array}{c}0.076 \\
(0.048)\end{array}$ & $\begin{array}{c}0.010 \\
(0.052)\end{array}$ & $\begin{array}{c}0.012 \\
(0.051)\end{array}$ & $\begin{array}{c}0.046 \\
(0.072)\end{array}$ & $\begin{array}{c}0.031 \\
(0.084)\end{array}$ & $\begin{array}{l}0.025 \\
(0.053)\end{array}$ \\
\hline NGO & $\begin{array}{l}-0.164 \\
(0.349)\end{array}$ & $\begin{array}{c}0.012 \\
(0.377)\end{array}$ & $\begin{array}{c}0.009 \\
(0.378)\end{array}$ & $\begin{array}{c}0.463 \\
(0.450)\end{array}$ & $\begin{array}{c}0.542 \\
(0.462)\end{array}$ & $\begin{array}{c}0.011 \\
(0.379)\end{array}$ & $\begin{array}{c}0.104 \\
(0.211)\end{array}$ & $\begin{array}{c}0.032 \\
(0.299)\end{array}$ & $\begin{array}{c}0.028 \\
(0.300)\end{array}$ & $\begin{array}{c}0.174 \\
(0.445)\end{array}$ & $\begin{array}{c}0.272 \\
(0.452)\end{array}$ & $\begin{array}{c}0.057 \\
(0.301)\end{array}$ \\
\hline OJSC & $\begin{array}{l}-0.013 \\
(0.110)\end{array}$ & $\begin{array}{c}0.028 \\
(0.116)\end{array}$ & $\begin{array}{c}0.032 \\
(0.116)\end{array}$ & $\begin{array}{c}0.226 \\
(0.164)\end{array}$ & $\begin{array}{c}0.148 \\
(0.199)\end{array}$ & $\begin{array}{c}0.026 \\
(0.118)\end{array}$ & $\begin{array}{l}-0.029 \\
(0.095)\end{array}$ & $\begin{array}{l}-0.038 \\
(0.099)\end{array}$ & $\begin{array}{l}-0.035 \\
(0.099)\end{array}$ & $\begin{array}{c}0.107 \\
(0.136)\end{array}$ & $\begin{array}{c}0.019 \\
(0.160)\end{array}$ & $\begin{array}{l}-0.030 \\
(0.101)\end{array}$ \\
\hline Other & $\begin{array}{c}0.294 \\
(0.219)\end{array}$ & $\begin{array}{c}0.320 \\
(0.208)\end{array}$ & $\begin{array}{c}0.318 \\
(0.209)\end{array}$ & $\begin{array}{c}0.712^{* * * *} \\
(0.259)\end{array}$ & $\begin{array}{c}0.839 * * * \\
(0.283)\end{array}$ & $\begin{array}{l}0.316 \\
(0.210)\end{array}$ & $\begin{array}{c}0.075 \\
(0.200)\end{array}$ & $\begin{array}{c}0.018 \\
(0.207)\end{array}$ & $\begin{array}{l}0.016 \\
(0.207)\end{array}$ & $\begin{array}{c}0.397 \\
(0.255)\end{array}$ & $\begin{array}{c}0.542^{* *} \\
(0.275)\end{array}$ & $\begin{array}{c}0.018 \\
(0.209)\end{array}$ \\
\hline State Ent & $\begin{array}{c}0.039 \\
(0.121)\end{array}$ & $\begin{array}{l}-0.079 \\
(0.142)\end{array}$ & $\begin{array}{l}-0.085 \\
(0.141)\end{array}$ & $\begin{array}{c}0.140 \\
(0.194)\end{array}$ & $\begin{array}{c}0.035 \\
(0.234)\end{array}$ & $\begin{array}{l}-0.072 \\
(0.145)\end{array}$ & $\begin{array}{c}0.104 \\
(0.103)\end{array}$ & $\begin{array}{c}0.028 \\
(0.114)\end{array}$ & $\begin{array}{l}0.025 \\
(0.114)\end{array}$ & $\begin{array}{c}0.170 \\
(0.163)\end{array}$ & $\begin{array}{c}0.205 \\
(0.185)\end{array}$ & $\begin{array}{c}0.051 \\
(0.117)\end{array}$ \\
\hline Trade Cooperative & $\begin{array}{c}0.218 \\
(0.141)\end{array}$ & $\begin{array}{l}0.243^{*} \\
(0.143)\end{array}$ & $\begin{array}{l}0.249^{*} \\
(0.142)\end{array}$ & $\begin{array}{c}0.418^{* *} \\
(0.188)\end{array}$ & $\begin{array}{c}0.314 \\
(0.228)\end{array}$ & $\begin{array}{l}0.251^{*} \\
(0.148)\end{array}$ & $\begin{array}{l}0.204^{*} \\
(0.112)\end{array}$ & $\begin{array}{l}0.202^{*} \\
(0.119)\end{array}$ & $\begin{array}{l}0.205^{*} \\
(0.119)\end{array}$ & $\begin{array}{c}0.332^{* *} \\
(0.154)\end{array}$ & $\begin{array}{c}0.265 \\
(0.174)\end{array}$ & $\begin{array}{l}0.221^{*} \\
(0.123)\end{array}$ \\
\hline & & & & & & & & & & & & \\
\hline Wald Chi2 & 1382 & 638.1 & 639 & 419.9 & 281.2 & 806.5 & 1387 & 748.7 & 746.2 & 554.4 & 355.5 & 855.9 \\
\hline $\begin{array}{l}\text { Pseudo-R2 } \\
\text { Firms }\end{array}$ & 0.0298 & 0.0286 & 0.0291 & 0.0427 & 0.0384 & 9,702 & 0.0395 & 0.0514 & 0.0517 & 0.0514 & 0.0400 & 10,219 \\
\hline
\end{tabular}

*** $\mathrm{p}<0.01, * * \mathrm{p}<0.05, * \mathrm{p}<0.1$

Notes: Table presents probit (columns 1-5 and 7-11) and population-averaged probit (columns 6 and 12) estimates of the determinants of bunching firms. Dummy for bunching firms is defined to be 1 if firm size is below $5 \%$ and $10 \%$ of the administrative threshold in columns 1-6 and 7-12 respectively, and 0 otherwise. All regressions include year and region ("Marz") fixed effects (not reported). Standard errors are clustered at the level of firms. 